\title{
Inequalities in health in Latin America and the Caribbean: descriptive and exploratory results for self-reported health problems and health care in twelve countries
}

\author{
J. Norberto W. Dachs, ${ }^{1}$ Marcela Ferrer, ${ }^{2}$ Carmen Elisa Florez, ${ }^{3}$ \\ Aluisio J. D. Barros, ${ }^{4}$ Rory Narváez, ${ }^{5}$ and Martín Valdivia ${ }^{6}$
}

ABSTRACT Objective. To explore and describe inequalities in health and use of health care as revealed by self-report in 12 countries of Latin America and the Caribbean.

Methods. A descriptive and exploratory study was performed based on the responses to questions on health and health care utilization that were included in general purpose household surveys. Inequalities are described by quintile of household expenditures (or income) per capita, sex, age group (children, adults, and older adults), and place of residence (urban vs. rural area). For those who sought health care, median polishing was performed by economic status and sex, for the three age groups.

Results. Although the study is exploratory and descriptive, its findings show large economic gradients in health care utilization in these countries, with generally small differences between males and females and higher percentages of women seeking health care than men, although there were some exceptions among the lower economic strata in urban areas.

Conclusions. Inequalities in self-reported health problems among the different economic strata were small, and such problems were usually more common among women than men. The presence of small inequalities may be due to cultural and social differences in the perception of health. However, in most countries included in the study, large inequalities were found in the use of health care for the self-reported health problems.

It is important to develop regional projects aimed at improving the questions on selfreported health in household interview surveys so that the determinants of the inequalities in health can be studied in depth. The authors conclude that due to the different patterns of economic gradients among different age groups and among males and females, the practice of standardization used in constructing concentration curves and in computing concentration indices should be avoided. At the end is a set of recommendations on how to improve these sources of data. Despite their shortcomings, household interview surveys are very useful in understanding the dimensions of health inequalities in these countries.

Key words Health inequalities, use of health services, self-reported health, household surveys, Latin America, Caribbean.

1 Program on Public Policy and Health, Division of Health and Human Development, Pan American Health Organization, Washington, D.C., United States of America. Please send all correspondence to either of the following addresses: Pan American Health Organization, 525 Twenty-third Street
N.W., Washington, D.C. 20037, United States of America. E-mail: dachsnor@paho.org

2 Universidad de Chile, Santiago, Chile.

3 Universidad de los Andes, Santa Fe de Bogotá, Colombia.
4 Universidade Federal de Pelotas, Pelotas, Rio Grande do Sul, Brazil.

5 Unidad de Análisis de Políticas Económicas y Sociales, Ministry of Finance, La Paz, Bolivia.

6 Grupo de Análisis para el Desarrollo (GRADE), Lima, Peru. 
Inequalities in health in Latin America and the Caribbean are large and, in some countries, they are increasing, although most average health indicators are improving. Most multi-purpose surveys used to measure living standards include a module on health with at least two types of questions: whether a health problem was experienced by anyone in the household and whether health care was sought for the problem. Since these surveys also contain information from which to compute indicators of socioeconomic status for households and individuals, it is possible to relate the observed differences in the responses to these questions to the economic status of the individuals $(1,2)$.

Because the question(s) on selfreported health problems evoke subjective responses (3) that differ across cultures and socioeconomic strata (4), it is not possible to use them to compare results from different countries. However, the responses to the questions on the health care sought for the self-reported health problems are less prone to subjectivity (8), although they do have other limitations, such as recall bias (5). Notwithstanding all these shortcomings, the exploratory and descriptive study presented in this paper shows that much can be learned about these inequalities by a careful analysis of these questions. The inequalities found in the utilization of the health system are very large, and would be even larger, perhaps, if these biases were factored into the analysis and the reliability of the data collection instruments used in the surveys were improved.

\section{Data sources and the survey questions}

The analysis was based on secondary data obtained from general purpose household surveys that were carried out in 1997, 1998, and 1999 in 11 Latin American countries as well as Jamaica in the Caribbean. With the exception of Argentina, where the survey covered only urban populations (close to $85 \%$ of the total population of

TABLE 1. Countries, names of the surveys, and years, for 12 countries of Latin America and the Caribbean

\begin{tabular}{llc}
\hline Country & \multicolumn{1}{c}{ Survey } & Year \\
\hline Argentina & Encuesta de Desarrollo Social & 1997 \\
Bolivia & Encuesta Permanente de Hogares (MECOVI) & 1999 \\
Brazil & Pesquisa de Padrões de Vida & 1997 \\
Chile & Encuesta de Caracterización Socio-Económica Nacional & 1998 \\
Colombia & Encuesta Nacional de Calidad de Vida & 1997 \\
Ecuador & Encuesta de Condiciones de Vida - tercera ronda & 1998 \\
El Salvador & Encuesta de Hogares de Propósitos Múltiples (MECOVI) & 1998 \\
Jamaica & Jamaica Survey of Living Conditions (LSMS) & 1998 \\
Nicaragua & Encuesta Nacional sobre Medición de Niveles de Vida (MECOVI) & 1998 \\
Panama & Encuesta de Niveles de Vida (LSMS) & 1997 \\
Paraguay & Encuesta Integrada de Hogares (MECOVI) & $1997 / 98$ \\
Peru & Encuesta Nacional de Niveles de VIDA (LSMS) & 1997 \\
\hline
\end{tabular}

the country), and Brazil, where it covered only two areas of the country (the Northeast and Southeast, which together account for approximately 70\% of the country's population), all other surveys were nationwide. Some of them were conducted as part of the World Bank's Living Standards Measurement Study, several others as part of the MECOVI ${ }^{7}$ program of the InterAmerican Development Bank, the World Bank, and the Economic Commission for Latin America and the Caribbean (ECLAC), and the remaining ones within the context of national projects and programs of the various national institutes of statistics or, in Chile, of the Ministry of Planning. Table 1 lists the countries, the names of the surveys, and the years they were conducted.

\section{The question on self-reported illness or injury ("health problem")}

The questions were different in each country, as shown in Appendix 1. The period covered by the question (or

\footnotetext{
The acronym MECOVI stands for the name of the Program in Spanish: Mejoramiento de las Encuestas y Medición de las Condiciones de Vida. In 2001, the Pan American Health Organization was incorporated as an associate member of this Program to work specifically in the area of health toward improving the instruments of data collection and stimulating utilization of health services and its determinants.
}

questions) differed greatly, along with the type of disease, sickness, illness, accident, injury, and other conditions included. Even if we disregard the fact that self-reporting of illness and accidents varies across cultures and socioeconomic strata (6-7), it is impossible to make comparisons between countries in terms of relative percentages.

There are two countries, Chile and Paraguay, for which the reference period is "the past three months." This is a long period and the recall bias is possibly high in these cases. In four other countries-Ecuador, El Salvador, Nicaragua and Panama - the reference period is one month, specifically "the past month". In three countriesArgentina, Brazil and Colombia-the reference period is 30 days, and in the three remaining countries-Bolivia, Jamaica, and Peru-it is four weeks. Questions that refer to "the past month" or the "past three months" are unclear as to the period to which they refer. If the interview was conducted, for example, on September 10, one does not know whether "the past month" refers to the period from August 10 to September 9 or to the month of August.

What is covered by the question also varies a great deal. All countries inquire about illnesses and accidents, but several explicitly provide other response choices. In Brazil, the term 
"health problems" is used, with different connotations for different respondents; in Chile, pregnancy is explicitly included; in Colombia and Ecuador, dental problems and aches are response options; and in El Salvador and Jamaica, crime- or violence-related injuries are included among the responses.

For the analysis only two categories will be considered: with a "health problem" and without a "health problem."

\section{The question on seeking health care}

In this section, the questions used to define the health care that was sought, as shown in Appendix 1, are discussed. There are important differences across countries that must be considered. In most cases, "health care" was considered a visit to a physician, dentist, or nurse, or, in some cases, a psychologist, a health promoter, or a community health worker. Community health workers and similar personnel were included under the assumption that a referral system was in place, something which may not be true in many settings, especially in rural areas. There are other countries where different categories had to be used because of the way the question and response options were presented. In Chile, the category was "health care", and the results will depend on how people in that country interpret this term. In Ecuador, it is not possible to tell whether care was sought from a physician, a nurse, or a traditional healer, and in Jamaica, all potential caregivers, from physician to healer to pharmacist, are lumped together in one category.

In all but two of the countries, El Salvador and Jamaica, the questions on "health care" applied only to those members of the household that reported having had a "health problem" during the reference period. The analysis in this study was restricted to persons who had a "health problem," as indicated by a "yes" response to the question.

In Brazil, restricting the question only to those cases in which, besides declaring an illness or an accident, there was also an interruption of normal everyday activities brought down the number of cases available, and it was not possible to perform the analysis for two of the age groups and for rural areas.

Because of all the discrepancies mentioned above, the responses to these questions do not allow for comparisons among countries in terms of health care services utilization.

\section{The distribution variable}

The two variables-presence or absence of a health problem and health care utilization-were analyzed by sex, age group, place of residence (urban vs. rural), and a distribution variable representing the economic status of members of the household. In nine of the countries the distribution variable was total household expenditure per capita, and in the remaining three (Argentina, Chile, and Paraguay) it was total household income per capita. When available, household expenditure is preferable to income for several reasons. It tends to be less biased, is less prone to seasonal variations, particulary in rural areas, and is considered a better indicator of household economic status overall (15).

This variable was broken down into quintiles, and the percentages of people who reported health problems and having sought health care by age group and sex, as well as by age group and place of residence, were distributed across those quintiles. For Bolivia and Colombia, total household expenditure per capita had to be computed from the original data. For the other 10 countries, total household income or expenditure per capita had already been computed by the institution that conducted the survey. In most cases this was the country's national institute of statistics, but in Argentina it was SIEMPRO (Sistema de Información, Monitoreo y Evaluación de Programas Sociales), a division of the Ministry of the Economy; in Chile, it was the Ministry of Planning (MIDEPLAN), and in Jamaica, it was the Planning Institute of Jamaica (PIOJ).
The age groups included in the analysis were not the same in all countries for two reasons. In Nicaragua, the questions were not asked for children under 6 , and in Panama for children under 5. Sample size was the other factor that determined the age groups included in the analysis. In some cases, the sample sizes for some categories ended up being too small in some age groups.

\section{RESULTS}

\section{Self-reported "health problem"}

Table 2 shows the percentages of people who declared having had a health problem or an accident, according to the categories presented above, by quintiles of household expenditure (or income) per capita, for three age groups that were loosely classified as children, adults, and older adults. The table also shows what age groups were included in each country. The choice of age groups was dictated in each country by two different factors. In some countries (see above) the question was not asked for children; in others, the sample sizes would be too small for some categories if the age groups were not increased. Table 3 shows the percentage of people who reported having had a health problem in each of the categories presented above, by quintiles of household expenditure (or income) per capita, in urban and rural areas. Sample sizes were not large enough to perform the data analysis by age group, quintiles of household expenditure (or income) per capita, and place of residence combined. In Argentina, the survey only covered urban areas, and in Panama the country was divided into four areas classified as urban, rural, hardto-reach rural, and indigenous.

\section{Self-reported health care}

Table 4 presents the percentages of people who reported having sought care for the reported "health problem" for each of the three age groups de- 
TABLE 2. Percentages of persons who were reported as having had a health problem or an accident, by quintile of household expenditure (or income) per capita and by sex, for three age groups in 12 countries of Latin America and the Caribbean

\begin{tabular}{|c|c|c|c|c|c|c|c|c|c|c|c|}
\hline \multirow[b]{3}{*}{ Country } & \multirow{3}{*}{$\begin{array}{c}\text { Age } \\
\text { group } \\
\text { (years) }\end{array}$} & \multicolumn{10}{|c|}{ Children } \\
\hline & & \multicolumn{5}{|c|}{ Boys } & \multicolumn{5}{|c|}{ Girls } \\
\hline & & 1 & 2 & 3 & 4 & 5 & 1 & 2 & 3 & 4 & 5 \\
\hline Bolivia & $0-4$ & 12.3 & 13.0 & 8.6 & 9.0 & 7.1 & 11.3 & 6.6 & 7.3 & 10.0 & 16.4 \\
\hline Brazil & $0-4$ & 37.8 & 34.9 & 35.0 & 32.1 & 34.9 & 29.4 & 25.7 & 26.7 & 30.4 & 29.2 \\
\hline Chile $^{a}$ & $0-4$ & 28.5 & 29.0 & 31.5 & 34.0 & 30.5 & 27.5 & 28.0 & 26.0 & 31.5 & 28.5 \\
\hline Ecuador & $0-14$ & 44.3 & 53.6 & 45.9 & 42.6 & 43.3 & 41.6 & 45.4 & 45.5 & 46.8 & 48.1 \\
\hline El Salvador & $0-4$ & 38.0 & 43.0 & 43.0 & 41.5 & 42.0 & 37.0 & 40.0 & 43.0 & 39.0 & 42.0 \\
\hline Jamaica & $0-4$ & 11.0 & 14.0 & 10.0 & 12.0 & 16.0 & 8.0 & 16.0 & 12.0 & 14.0 & 15.0 \\
\hline Nicaragua & $6-19$ & 31.0 & 30.0 & 32.0 & 30.0 & 30.0 & 32.0 & 31.0 & 36.0 & 35.0 & 37.0 \\
\hline Panama & $5-14$ & 23.0 & 32.5 & 32.0 & 32.5 & 35.0 & 23.2 & 32.0 & 28.8 & 34.0 & 37.8 \\
\hline Paraguaya & $0-4$ & 71.0 & 65.0 & 56.0 & 51.0 & 64.0 & 67.0 & 56.0 & 64.0 & 63.0 & 57.0 \\
\hline
\end{tabular}

\begin{tabular}{|c|c|c|c|c|c|c|c|c|c|c|c|}
\hline \multirow[b]{3}{*}{ Country } & \multirow{3}{*}{$\begin{array}{c}\text { Age } \\
\text { group } \\
\text { (years) }\end{array}$} & \multicolumn{10}{|c|}{ Adults } \\
\hline & & \multicolumn{5}{|c|}{ Men } & \multicolumn{5}{|c|}{ Women } \\
\hline & & 1 & 2 & 3 & 4 & 5 & 1 & 2 & 3 & 4 & 5 \\
\hline Bolivia & $15-44$ & 16.7 & 14.6 & 10.3 & 11.3 & 11.6 & 28.9 & 17.1 & 16.0 & 14.6 & 12.4 \\
\hline Brazil & $15-44$ & 17.8 & 16.5 & 14.1 & 16.9 & 17.0 & 23.1 & 19.9 & 18.0 & 20.5 & 17.2 \\
\hline Chile & $15-49$ & 15.0 & 15.0 & 15.0 & 15.3 & 15.9 & 21.5 & 20.3 & 20.5 & 20.7 & 20.9 \\
\hline El Salvador & $15-49$ & 23.3 & 21.1 & 20.9 & 20.1 & 19.0 & 24.3 & 23.8 & 23.6 & 23.4 & 21.5 \\
\hline Jamaica & $15-49$ & 3.0 & 5.0 & 3.0 & 4.0 & 6.0 & 6.0 & 6.0 & 8.0 & 7.0 & 8.0 \\
\hline Nicaragua & $20-49$ & 30.0 & 30.0 & 32.0 & 24.0 & 29.0 & 36.0 & 39.0 & 34.0 & 35.0 & 34.0 \\
\hline Panama & $15-64$ & 28.0 & 26.3 & 26.0 & 28.8 & 25.0 & 37.8 & 37.3 & 37.0 & 39.0 & 39.3 \\
\hline Paraguaya & $15-49$ & 27.4 & 23.4 & 18.8 & 22.1 & 21.9 & 32.9 & 25.7 & 25.6 & 26.3 & 27.8 \\
\hline
\end{tabular}

\begin{tabular}{|c|c|c|c|c|c|c|c|c|c|c|c|}
\hline \multirow[b]{3}{*}{ Country } & \multirow{3}{*}{$\begin{array}{c}\text { Age } \\
\text { group } \\
\text { (years) }\end{array}$} & \multicolumn{10}{|c|}{ Older adults } \\
\hline & & \multicolumn{5}{|c|}{ Men } & \multicolumn{5}{|c|}{ Women } \\
\hline & & 1 & 2 & 3 & 4 & 5 & 1 & 2 & 3 & 4 & 5 \\
\hline Bolivia & $65+$ & 47.4 & 48.0 & 47.8 & 40.9 & 42.7 & 51.5 & 46.8 & 54.1 & 42.2 & 47.7 \\
\hline Brazil & $65+$ & 36.4 & 37.2 & 38.1 & 19.5 & 18.5 & 37.9 & 32.6 & 34.8 & 28.0 & 31.4 \\
\hline Chile $^{a}$ & $65+$ & 33.7 & 34.2 & 33.0 & 30.5 & 24.9 & 38.4 & 40.0 & 40.3 & 40.3 & 43.0 \\
\hline Ecuador & $50+$ & 56.8 & 64.5 & 60.1 & 56.8 & 46.5 & 67.5 & 71.7 & 66.2 & 71.5 & 59.9 \\
\hline El Salvador & $50+$ & 31.1 & 29.8 & 26.3 & 27.2 & 26.0 & 33.5 & 33.3 & 37.2 & 31.5 & 31.9 \\
\hline Jamaica & $65+$ & 25.0 & 19.0 & 24.0 & 19.0 & 20.0 & 30.0 & 32.0 & 28.0 & 25.0 & 33.0 \\
\hline Nicaragua & $50+$ & 47.0 & 53.0 & 57.0 & 45.0 & 46.0 & 48.0 & 58.0 & 56.0 & 60.0 & 63.0 \\
\hline Panama & $65+$ & 46.3 & 50.5 & 42.0 & 42.0 & 28.5 & 52.0 & 57.0 & 45.3 & 49.5 & 42.0 \\
\hline Paraguay ${ }^{a}$ & $50+$ & 45.8 & 38.7 & 33.0 & 30.2 & 23.4 & 52.2 & 42.4 & 49.2 & 43.8 & 35.7 \\
\hline
\end{tabular}

${ }^{a}$ In Argentina, Chile, and Paraguay the distribution variable was income per capita. 
TABLE 3. Percentages of persons in urban and rural areas who were reported as having had a health problem or an accident, by quintile of household expenditure (or income) per capita and by sex, in $10^{\mathrm{a}}$ countries of Latin America and the Caribbean

\begin{tabular}{|c|c|c|c|c|c|c|c|c|c|c|}
\hline \multirow[b]{3}{*}{ Country } & \multicolumn{10}{|c|}{ Urban Area } \\
\hline & \multicolumn{5}{|c|}{ Males } & \multicolumn{5}{|c|}{ Females } \\
\hline & 1 & 2 & 3 & 4 & 5 & 1 & 2 & 3 & 4 & 5 \\
\hline Brazil & 23.8 & 20.3 & 20.9 & 19.0 & 19.0 & 25.0 & 21.2 & 21.7 & 21.8 & 18.9 \\
\hline Chile $^{b}$ & 20.0 & 20.0 & 20.0 & 19.5 & 19.0 & 24.9 & 24.2 & 24.0 & 24.3 & 25.5 \\
\hline Colombia & 17.0 & 17.0 & 17.0 & 18.0 & 21.0 & 18.0 & 22.0 & 23.0 & 27.0 & 25.0 \\
\hline Jamaica & 5.4 & 7.2 & 5.5 & 5.3 & 7.3 & 5.8 & 9.0 & 8.5 & 7.9 & 8.1 \\
\hline Nicaragua & 27.0 & 30.0 & 30.0 & 25.0 & 28.0 & 32.0 & 34.0 & 35.0 & 35.0 & 37.0 \\
\hline Paraguayb & 40.4 & 30.5 & 27.7 & 27.8 & 28.2 & 43.9 & 33.9 & 31.5 & 33.2 & 32.6 \\
\hline Peru & 27.7 & 24.0 & 17.7 & 18.7 & 19.2 & 30.0 & 24.3 & 21.7 & 22.9 & 24.8 \\
\hline
\end{tabular}

\begin{tabular}{|c|c|c|c|c|c|c|c|c|c|c|}
\hline \multirow{2}{*}{ Country } & \multicolumn{10}{|c|}{ Rural Area } \\
\hline & \multicolumn{5}{|c|}{ Males } & \multicolumn{5}{|c|}{ Females } \\
\hline Brazil & 23.3 & 25.1 & 24.2 & 31.8 & 16.1 & 25.0 & 27.3 & 26.3 & 31.5 & 12.8 \\
\hline Chile $^{b}$ & 22.2 & 19.5 & 19.0 & 18.7 & 15.2 & 23.4 & 22.0 & 23.0 & 21.8 & 20.4 \\
\hline Colombia & 12.0 & 17.0 & 16.0 & 22.0 & 22.0 & 16.0 & 20.0 & 23.0 & 25.0 & 31.0 \\
\hline Jamaica & 8.3 & 8.9 & 8.1 & 8.4 & 8.9 & 11.5 & 11.2 & 11.9 & 11.6 & 16.9 \\
\hline Nicaragua & 33.0 & 34.0 & 42.0 & 37.0 & 47.0 & 37.0 & 41.0 & 42.0 & 48.0 & 52.0 \\
\hline Paraguay $^{b}$ & 39.3 & 33.0 & 26.7 & 27.5 & 24.7 & 40.2 & 32.6 & 36.6 & 33.9 & 34.6 \\
\hline Peru & 25.8 & 25.3 & 25.4 & 20.1 & 28.5 & 25.5 & 30.0 & 27.9 & 30.2 & 33.8 \\
\hline
\end{tabular}

a In Argentina, the survey covered only urban areas, and in Panama it covered four areas categorized as urban, rural, hard-to-reach rural, and indigenous.

${ }^{\mathrm{b}}$ In Chile and Paraguay, the distribution variable was income per capita.

fined for "health problem" above, as well as by sex and quintile of household expenditure (or income) per capita. For Brazil, the results for children and older adults are not shown since sample sizes were too small in some cells. ${ }^{8}$ Table 5 shows the percentages of people who sought health care, by sex, in urban and rural areas. Once again, in Argentina the survey only covered urban areas, and in Panama the country was divided into four areas classified as urban, rural, hardto-reach rural, and indigenous. In

\footnotetext{
8 Some cells were too small because they included only those individuals whose "health problem" had also led them to interrupt their normal daily activities.
}

Brazil the sample sizes were too small in rural areas.

\section{DISCUSSION}

\section{Self-reported health problem}

Self-reporting of health problems, including accidents, is fraught with difficulties. The first of them is recall bias, which tends to differ depending on social and economic status, sex, and urban and rural residence, and which is impossible to estimate from interview survey data. The second one is the fact that in all the surveys included in this study, the reporting was done in most cases by only one member of the household, usually an adult woman who was more likely to be present when the interviewer came to obtain the data. Reporting minor ailments for other adult members of the household is seldom done because the individual providing the information is not always aware they occurred. Another difficulty stems from the fact that culture and the amount of information people have play a part in the perception of disease. So do an individual's educational level and economic status, which determine his/ her access to facts, myths, and so forth.

The questions on health problems covered a different period of time in each country; in some cases this was very explicit, and in others quite 
TABLE 4. Percentages of persons who received health care among those who were reported as having had a health problem or an accident, by quintile of household expenditure (or income) per capita and sex, for three age groups, in 12 countries of Latin America and the Caribbean

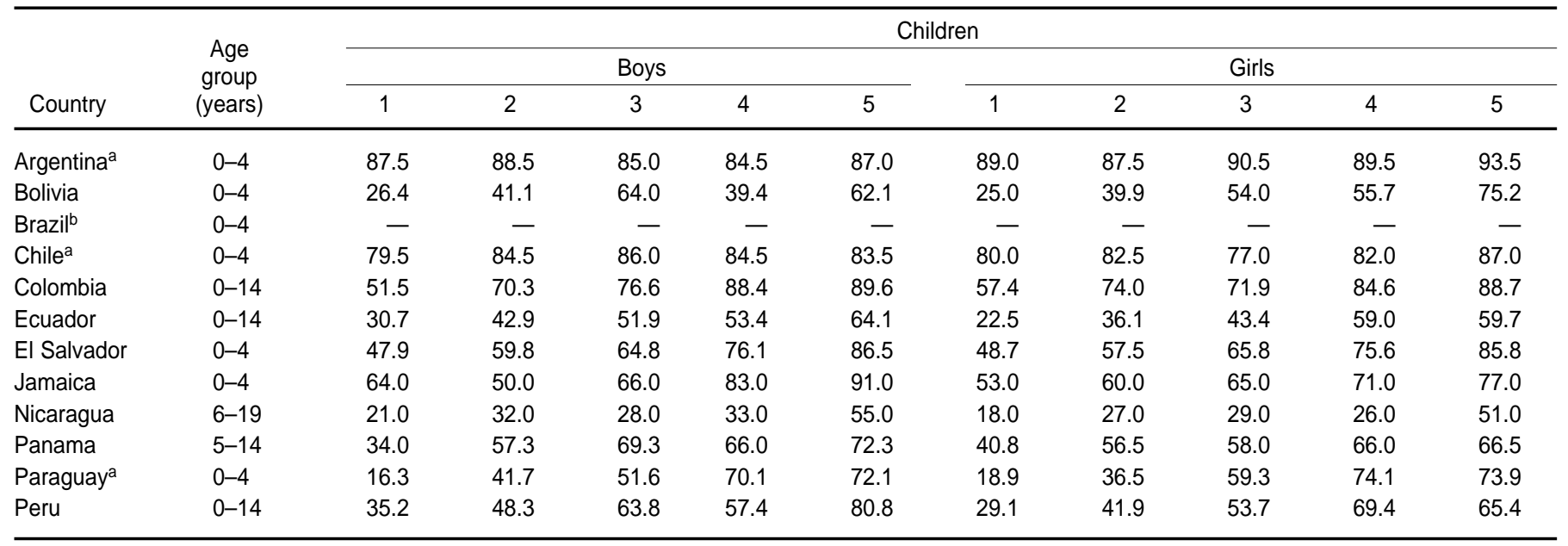

\begin{tabular}{|c|c|c|c|c|c|c|c|c|c|c|c|}
\hline \multirow[b]{3}{*}{ Country } & \multirow{3}{*}{$\begin{array}{l}\text { Age } \\
\text { group } \\
\text { (years) }\end{array}$} & \multicolumn{10}{|c|}{ Adults } \\
\hline & & \multicolumn{5}{|c|}{ Men } & \multicolumn{5}{|c|}{ Women } \\
\hline & & 1 & 2 & 3 & 4 & 5 & 1 & 2 & 3 & 4 & 5 \\
\hline Argentina $a^{a}$ & $15-64$ & 60.3 & 62.9 & 75.2 & 69.4 & 65.4 & 70.8 & 76.8 & 74.8 & 76.5 & 83.4 \\
\hline Bolivia & $15-44$ & 29.0 & 63.6 & 53.2 & 68.1 & 81.7 & 37.8 & 52.7 & 70.2 & 53.6 & 86.0 \\
\hline Brazil & $15-64$ & 43.8 & 62.0 & 61.8 & 69.6 & 80.4 & 53.6 & 55.7 & 46.0 & 74.4 & 67.2 \\
\hline Chile $^{a}$ & $15-49$ & 59.2 & 65.0 & 77.5 & 79.7 & 78.7 & 70.2 & 71.2 & 71.7 & 72.0 & 79.0 \\
\hline Colombia & $15-49$ & 56.4 & 63.0 & 77.9 & 79.1 & 81.4 & 72.8 & 74.1 & 84.4 & 85.6 & 87.0 \\
\hline Ecuador & $15-49$ & 29.2 & 39.4 & 34.2 & 48.7 & 50.8 & 31.4 & 36.2 & 36.4 & 50.6 & 51.3 \\
\hline El Salvador & $15-49$ & 22.5 & 31.3 & 40.3 & 48.8 & 53.2 & 31.5 & 45.2 & 51.5 & 59.0 & 60.8 \\
\hline Jamaica & $15-49$ & 57.0 & 56.0 & 50.0 & 68.0 & 52.0 & 61.0 & 54.0 & 53.0 & 67.0 & 62.0 \\
\hline Nicaragua & $20-49$ & 22.0 & 34.0 & 40.0 & 43.0 & 49.0 & 29.0 & 35.0 & 42.0 & 46.0 & 50.0 \\
\hline Panama & $15-64$ & 33.3 & 44.3 & 60.0 & 61.0 & 55.3 & 37.5 & 54.3 & 60.5 & 58.8 & 60.8 \\
\hline Paraguay ${ }^{\mathrm{a}}$ & $15-49$ & 23.0 & 41.5 & 54.5 & 60.0 & 64.5 & 31.0 & 42.5 & 52.5 & 64.0 & 66.0 \\
\hline Peru & $15-44$ & 22.7 & 26.9 & 30.7 & 37.1 & 34.1 & 25.6 & 34.1 & 41.1 & 44.3 & 45.1 \\
\hline
\end{tabular}

\begin{tabular}{|c|c|c|c|c|c|c|c|c|c|c|c|}
\hline \multirow[b]{3}{*}{ Country } & \multirow{3}{*}{$\begin{array}{l}\text { Age } \\
\text { group } \\
\text { (years) }\end{array}$} & \multicolumn{10}{|c|}{ Older adults } \\
\hline & & \multicolumn{5}{|c|}{ Men } & \multicolumn{5}{|c|}{ Women } \\
\hline & & 1 & 2 & 3 & 4 & 5 & 1 & 2 & 3 & 4 & 5 \\
\hline Argentina $\mathrm{a}^{\mathrm{a}}$ & $65+$ & 71.0 & 79.0 & 78.5 & 82.0 & 86.5 & 83.0 & 85.0 & 81.5 & 83.5 & 87.0 \\
\hline Bolivia & $65+$ & 26.8 & 40.6 & 58.0 & 57.2 & 75.8 & 28.3 & 41.9 & 59.4 & 55.5 & 72.4 \\
\hline Brazil ${ }^{b}$ & $65+$ & - & - & - & - & - & - & - & - & - & - \\
\hline Chilea & $65+$ & 73.5 & 80.5 & 84.5 & 81.5 & 89.5 & 77.0 & 81.0 & 83.0 & 87.0 & 86.5 \\
\hline Colombia & $50+$ & 57.3 & 77.9 & 77.7 & 93.0 & 90.2 & 69.4 & 79.4 & 86.3 & 90.3 & 92.4 \\
\hline Ecuador & $50+$ & 35.5 & 44.4 & 50.5 & 60.7 & 63.5 & 37.4 & 45.6 & 42.4 & 62.0 & 68.6 \\
\hline El Salvador & $50+$ & 26.3 & 30.8 & 41.5 & 44.6 & 71.8 & 35.1 & 41.5 & 49.4 & 53.9 & 73.5 \\
\hline Jamaica & $65+$ & 54.0 & 44.0 & 66.0 & 66.0 & 62.0 & 63.0 & 57.0 & 69.0 & 77.0 & 78.0 \\
\hline Nicaragua & $50+$ & 34.0 & 43.0 & 36.0 & 48.0 & 49.0 & 34.0 & 37.0 & 44.0 & 48.0 & 54.0 \\
\hline Panama & $65+$ & 35.5 & 61.5 & 78.5 & 78.0 & 61.3 & 52.0 & 66.0 & 80.0 & 83.8 & 79.8 \\
\hline Paraguaya & $50+$ & 31.6 & 49.2 & 59.9 & 63.4 & 67.1 & 42.6 & 44.6 & 60.5 & 71.6 & 86.7 \\
\hline Peru & $65+$ & 36.2 & 36.6 & 49.1 & 60.8 & 66.4 & 25.9 & 37.8 & 48.8 & 52.7 & 64.2 \\
\hline
\end{tabular}

a In Argentina, Chile, and Paraguay the distribution variable was income per capita.

b The sample size in Brazil was not large enough to study this age group. 
TABLE 5. Percentages of people in urban and rural areas who sought health care among those who were reported as having had a health problem or an accident, by quintile of household expenditure (or income) per capita and sex, in $10^{\mathrm{a}}$ countries of Latin America and the Caribbean

\begin{tabular}{|c|c|c|c|c|c|c|c|c|c|c|}
\hline \multirow[b]{3}{*}{ Country } & \multicolumn{10}{|c|}{ Urban area } \\
\hline & \multicolumn{5}{|c|}{ Males } & \multicolumn{5}{|c|}{ Females } \\
\hline & 1 & 2 & 3 & 4 & 5 & 1 & 2 & 3 & 4 & 5 \\
\hline Brazil & 50.5 & 61.0 & 57.2 & 71.9 & 67.3 & 58.3 & 59.3 & 55.0 & 68.5 & 75.7 \\
\hline Chile $^{b}$ & 71.5 & 74.2 & 74.7 & 74.7 & 78.4 & 74.5 & 74.9 & 75.0 & 76.9 & 82.2 \\
\hline Colombia & 59.0 & 73.0 & 82.0 & 87.0 & 85.0 & 74.0 & 80.0 & 83.0 & 88.0 & 89.0 \\
\hline Jamaica & 67.4 & 45.0 & 59.6 & 63.1 & 61.5 & 62.5 & 46.4 & 53.6 & 71.3 & 64.6 \\
\hline Nicaragua & 21.0 & 38.0 & 37.0 & 37.0 & 47.0 & 22.0 & 32.0 & 36.0 & 44.0 & 51.0 \\
\hline Paraguayb & 27.6 & 38.0 & 56.9 & 56.6 & 63.4 & 33.6 & 40.0 & 58.8 & 68.7 & 74.4 \\
\hline Peru & 25.6 & 38.2 & 40.9 & 45.1 & 50.1 & 20.2 & 39.6 & 44.2 & 50.5 & 54.8 \\
\hline
\end{tabular}

\begin{tabular}{|c|c|c|c|c|c|c|c|c|c|c|}
\hline \multirow[b]{3}{*}{ Country } & \multicolumn{10}{|c|}{ Rural area } \\
\hline & \multicolumn{5}{|c|}{ Males } & \multicolumn{5}{|c|}{ Females } \\
\hline & 1 & 2 & 3 & 4 & 5 & 1 & 2 & 3 & 4 & 5 \\
\hline Brazil & 43.1 & 49.3 & 53.0 & 63.1 & 78.7 & 37.3 & 49.7 & 63.2 & 59.1 & 100.0 \\
\hline Chile $^{b}$ & 57.7 & 63.0 & 63.7 & 66.0 & 61.4 & 65.0 & 70.7 & 73.2 & 73.9 & 71.4 \\
\hline Colombia & 51.0 & 63.0 & 63.0 & 75.0 & 84.0 & 64.0 & 66.0 & 77.0 & 78.0 & 84.0 \\
\hline Jamaica & 55.3 & 49.1 & 56.0 & 67.8 & 57.6 & 60.7 & 62.7 & 65.4 & 72.7 & 71.1 \\
\hline Nicaragua & 24.0 & 34.0 & 34.0 & 37.0 & 49.0 & 27.0 & 34.0 & 38.0 & 38.0 & 50.0 \\
\hline Paraguay ${ }^{b}$ & 19.2 & 35.0 & 45.4 & 57.9 & 50.4 & 24.4 & 36.4 & 51.7 & 55.5 & 64.5 \\
\hline Peru & 28.5 & 26.9 & 38.3 & 43.5 & 39.3 & 25.5 & 29.7 & 44.6 & 47.2 & 35.6 \\
\hline
\end{tabular}

\footnotetext{
a In Argentina, the survey covered only urban areas, and in Panama it covered four areas categorized as urban, rural, hard-to-reach rural, and indigenous.
}

$\mathrm{b}$ In Chile and Paraguay the distribution variable was income per capita.

vague. This explains to a large extent the observed differences in the average percentages of people for whom a health problem was reported, which range from close to $12 \%$ in Jamaica and Bolivia to over $60 \%$ in Paraguay among children, from 5\% in Jamaica to almost $40 \%$ in Ecuador among adults, and from close to $20 \%$ in Jamaica to almost $60 \%$ in Ecuador among older adults. Interestingly, the percentages were not highest in Chile and Nicaragua, the two countries having the longest reference period (three months). In most countries, there was little urban/ rural variation for the averages, but there were large disparities according to economic status.
One of the reasons for the much lower percentages observed in Jamaica, the only English-speaking country in the study, may have been the phrasing of the question regarding a perceived health problem- "Have you had any illness?" - and gave a cold and diarrhea as response options. This may have kept individuals who had a chronic illness or other health problems from answering yes to the question. The Jamaican survey also included questions about how long the illness lasted and how many days the individual who was ill had to interrupt his/her "normal activities" because of it. The average number of days the illness or injury lasted was 11 , and the av- erage number of days of inactivity due to this illness or injury was 6 (8). These figures suggest that only the more severe cases were being reported by the persons interviewed in this survey.

Tables 6 and 7 show the results of median polishing for the data in Tables 1 and 2 (see Appendix 2 for a technical description of the method). Jamaica was excluded from the polishing partly because in that country the percentages for the five quintiles of expenditure per capita behaved erratically, perhaps because the two questions asked in the interview survey were worded in a complicated way.

In general, there is very little variation across expenditure (or income) 
TABLE 6. Results of median polishing for percentages of persons who were reported as having had a health problem by quintile of household expenditure (or income) per capita and by sex, for three age groups in 11 countries of Latin America

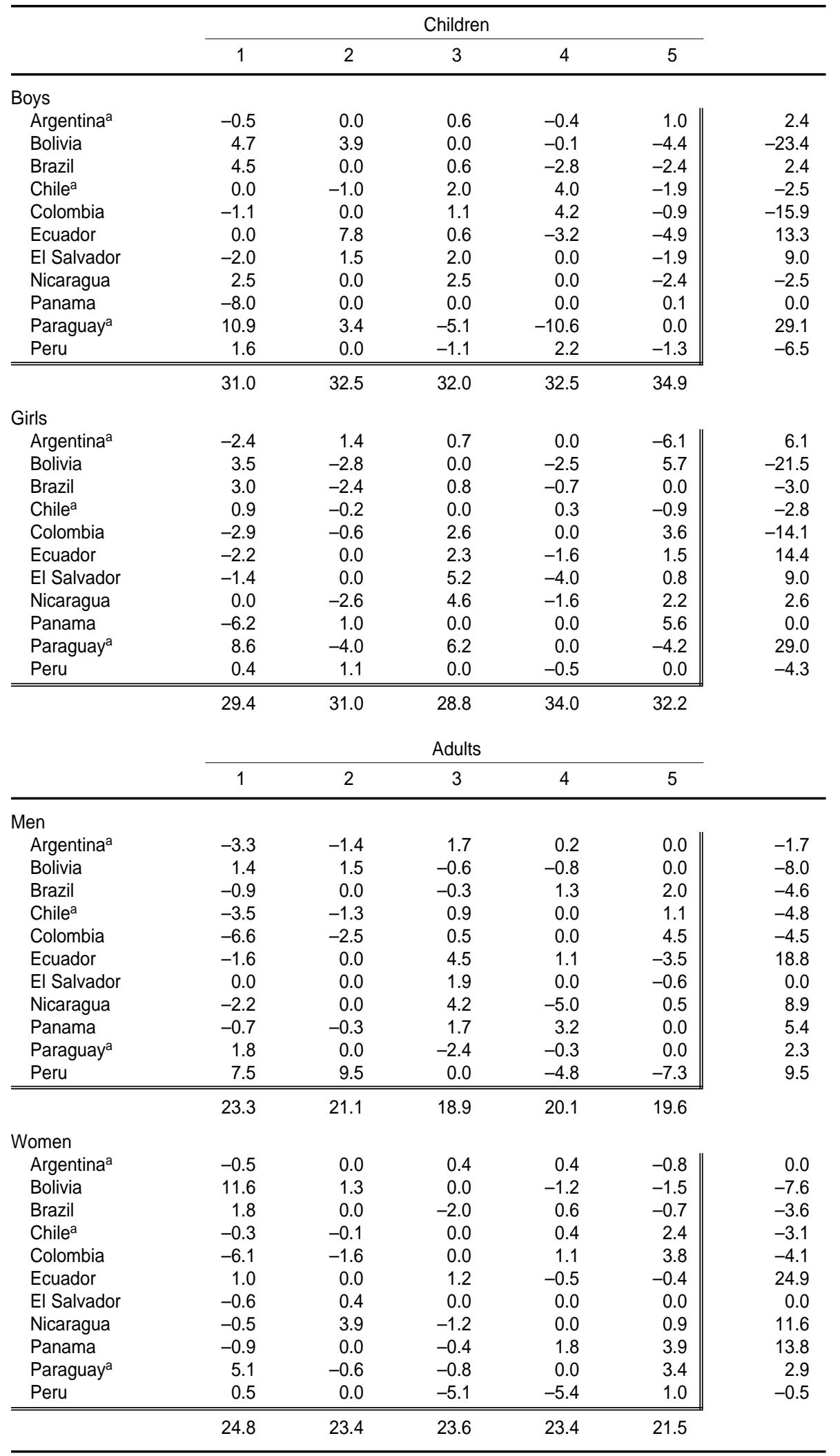


TABLE 6. (Continued)

\begin{tabular}{|c|c|c|c|c|c|c|}
\hline & \multicolumn{5}{|c|}{ Older Adults } & \\
\hline & 1 & 2 & 3 & 4 & 5 & \\
\hline \multicolumn{7}{|l|}{ Men } \\
\hline Argentina $^{a}$ & -2.7 & 0.0 & 3.3 & 1.2 & -1.6 & 1.6 \\
\hline Bolivia & 0.6 & -1.1 & -0.6 & 0.0 & 5.9 & 10.4 \\
\hline Brazil & 1.5 & 0.0 & 1.5 & -9.5 & -6.4 & -1.5 \\
\hline Chile $^{a}$ & 0.0 & -1.8 & -2.3 & 2.8 & 1.2 & -2.8 \\
\hline Colombia & -4.5 & -1.0 & 0.0 & 5.3 & 17.9 & -13.0 \\
\hline Ecuador & -1.7 & 3.7 & 0.0 & 4.3 & -2.0 & 22.1 \\
\hline El Salvador & 0.0 & -3.6 & -6.4 & 2.1 & 4.9 & -5.4 \\
\hline Nicaragua & -3.9 & -0.2 & 4.4 & 0.0 & 5.0 & 14.5 \\
\hline Panama & 0.0 & 2.0 & -5.9 & 1.7 & -7.8 & 9.8 \\
\hline Paraguaya & 9.7 & 0.3 & -4.8 & 0.0 & -2.8 & -0.3 \\
\hline \multirow[t]{2}{*}{ Peru } & 0.0 & -4.7 & -4.0 & 6.5 & 9.8 & -9.8 \\
\hline & 36.4 & 38.7 & 38.1 & 30.5 & 26.5 & \\
\hline \multicolumn{7}{|l|}{ Women } \\
\hline Argentina & -1.8 & 1.2 & -0.3 & 0.0 & 1.8 & 0.3 \\
\hline Bolivia & 1.5 & -1.3 & 6.2 & -5.7 & 0.0 & 5.7 \\
\hline Brazil & 3.4 & 0.0 & 2.4 & -4.4 & -0.8 & -9.8 \\
\hline Chile $^{a}$ & -4.0 & -0.5 & 0.0 & 0.0 & 2.9 & -1.9 \\
\hline Colombia & -8.6 & -1.4 & 0.0 & 4.5 & 4.6 & -11.8 \\
\hline Ecuador & -0.8 & 5.3 & 0.0 & 5.3 & -6.1 & 24.0 \\
\hline El Salvador & -0.6 & 1.0 & 5.2 & -0.6 & 0.0 & -10.2 \\
\hline Nicaragua & -11.8 & 0.0 & -1.8 & 2.2 & 5.4 & 15.6 \\
\hline Panama & 0.4 & 7.3 & -4.2 & 0.0 & -7.3 & 7.3 \\
\hline Paraguaya & 6.3 & -1.6 & 5.4 & 0.0 & -7.9 & 1.6 \\
\hline \multirow[t]{2}{*}{ Peru } & 4.8 & 3.5 & 0.0 & -4.9 & -7.1 & -4.8 \\
\hline & 44.2 & 42.4 & 42.2 & 42.2 & 42.0 & \\
\hline
\end{tabular}

a In Argentina, Chile, and Paraguay the distribution variable was income per capita.

quintiles for all age groups in urban and rural areas, with the exception of women in rural areas, who showed higher percentages in the quintiles of greater expenditure per capita. Although our analysis is merely exploratory and descriptive in nature, the fact that the residuals are "small" in almost every case supports the statement that there are no important differences across the various economic strata in the frequency of selfreported health problems in these countries.

The differences by sex are also generally small, except among older adults. In this group, the percentage of women with a self-reported health problem was between 5 and 15 points higher than for men, which is partly due to the fact that women live longer than men and thus, in older age groups, there are proportionately more women in poor health.

Again no comparisons across countries can be made for the reasons already explained.

\section{Health care}

The percentages of children who sought health care for their reported health problems ranged from close to 30 in Nicaragua to over 80 in Chile and Argentina. These differences are due in part to greater access to health care in some countries than others, but also to the seriousness of the "problem" being reported, which may differ, in turn, depending on the phrasing of the questions asked to obtain that information. If the problems were more serious in one case than another, the percentage of health care utilization would be higher in the country reporting the more serious problems, even for similar levels of access to care. Another factor that can influence these results is the perception of health and disease, which varies according to cultural and socioeconomic background. Colombia and Peru are good examples. The questions included in the surveys were similar in both countries. The percentage of children that were reported as having had a health problem was close to $10 \%$ higher in Peru than in Colombia across all quintiles of expenditure per capita (see Tables 2 
TABLE 7. Results of median polishing for the percentages of persons in urban and rural areas who were reported as having had a health problem, by quintile of household expenditure (or income) per capita and sex, in nine ${ }^{\mathrm{a}}$ countries of Latin America

\begin{tabular}{|c|c|c|c|c|c|c|}
\hline & \multicolumn{5}{|c|}{ Urban Area } & \\
\hline & 1 & 2 & 3 & 4 & 5 & \\
\hline \multicolumn{7}{|l|}{ Men } \\
\hline Bolivia & 5.7 & -1.3 & -2.7 & 1.7 & 0.0 & -7.9 \\
\hline Brazil & 0.5 & -1.9 & 0.5 & 0.0 & -1.5 & -0.5 \\
\hline Chile $^{b}$ & -1.8 & -0.7 & 1.1 & 2.0 & 0.0 & -2.0 \\
\hline Colombia & -2.9 & -1.8 & 0.0 & 2.4 & 3.9 & -3.9 \\
\hline Ecuador & -1.3 & 3.4 & 3.0 & 0.0 & -3.7 & 19.8 \\
\hline El Salvador & -3.0 & -1.3 & 1.6 & 3.1 & 0.0 & 1.3 \\
\hline Nicaragua & -3.8 & 0.3 & 2.1 & -1.5 & 0.0 & 7.0 \\
\hline Paraguay ${ }^{b}$ & 8.8 & 0.0 & -1.0 & 0.5 & -0.6 & 7.8 \\
\hline \multirow[t]{2}{*}{ Peru } & 4.7 & 2.1 & -2.4 & 0.0 & -1.0 & -0.8 \\
\hline & 23.8 & 22.7 & 20.9 & 19.5 & 21.0 & \\
\hline \multicolumn{7}{|l|}{ Women } \\
\hline Bolivia & 6.2 & -1.8 & -0.8 & 0.0 & 0.1 & -10.8 \\
\hline Brazil & 3.1 & 0.0 & 0.7 & -0.6 & -3.1 & -3.1 \\
\hline Chile $^{b}$ & 0.0 & 0.0 & 0.1 & -1.0 & 0.6 & -0.1 \\
\hline Colombia & -6.0 & -1.3 & 0.0 & 2.6 & 1.0 & -1.0 \\
\hline Ecuador & 1.8 & 0.0 & 1.4 & 0.0 & 0.0 & 23.2 \\
\hline El Salvador & -3.3 & 1.4 & 0.4 & 0.0 & -1.0 & 0.0 \\
\hline Nicaragua & -2.7 & 0.0 & 1.3 & -0.1 & 2.3 & 9.7 \\
\hline Paraguay ${ }^{b}$ & 11.1 & 1.8 & -0.3 & 0.0 & -0.2 & 7.8 \\
\hline \multirow[t]{2}{*}{ Peru } & 5.2 & 0.2 & -2.1 & -2.3 & 0.0 & -0.2 \\
\hline & 25.0 & 24.3 & 24.0 & 25.4 & 25.0 & \\
\hline
\end{tabular}

\begin{tabular}{|c|c|c|c|c|c|c|}
\hline & & & ural $\mathrm{Ar}$ & & & \\
\hline & 1 & 2 & 3 & 4 & 5 & \\
\hline Men & & & & & & \\
\hline Bolivia & 0.0 & -0.5 & 1.2 & -3.4 & 6.3 & -5.2 \\
\hline Brazil & -1.4 & 0.9 & 0.0 & 5.5 & -11.2 & -1.2 \\
\hline Chile $^{b}$ & 2.7 & 0.6 & 0.0 & -2.4 & -6.9 & -6.4 \\
\hline Colombia & -5.5 & 0.0 & -1.1 & 2.8 & 1.8 & -8.3 \\
\hline Ecuador & -5.8 & -0.7 & 0.0 & 3.1 & 3.2 & 24.9 \\
\hline El Salvador & -1.2 & 0.0 & 0.3 & -2.8 & 0.7 & 2.9 \\
\hline Nicaragua & -2.3 & -0.8 & 7.1 & 0.0 & 9.0 & 9.5 \\
\hline Paraguayb & 12.2 & 6.4 & 0.0 & -1.3 & -5.0 & 1.3 \\
\hline Peru & 0.0 & 0.0 & 0.0 & -7.4 & 0.0 & 0.0 \\
\hline & 25.8 & 25.3 & 25.4 & 27.5 & 28.5 & \\
\hline Women & & & & & & \\
\hline Bolivia & 2.5 & -4.3 & 0.0 & -2.6 & 8.8 & -2.5 \\
\hline Brazil & -0.2 & 0.3 & 0.0 & 1.6 & -20.2 & -1.6 \\
\hline Chile $^{b}$ & 3.1 & 0.0 & 1.7 & -3.1 & -7.6 & -6.6 \\
\hline Colombia & -4.3 & -2.1 & 1.6 & 0.0 & 2.9 & -6.5 \\
\hline Ecuador & -2.5 & 0.0 & 2.5 & 0.7 & -1.4 & 26.1 \\
\hline El Salvador & 0.0 & -1.4 & 2.8 & -1.3 & 1.3 & 1.4 \\
\hline Nicaragua & -3.9 & -1.7 & 0.0 & 2.4 & 3.3 & 14.1 \\
\hline Paraguayb & 9.4 & 0.0 & 4.7 & -1.6 & -4.0 & 4.0 \\
\hline Peru & -0.5 & 2.2 & 0.8 & -0.5 & 0.0 & -0.8 \\
\hline & 26.8 & 28.6 & 27.9 & 31.5 & 34.6 & \\
\hline
\end{tabular}

a In Argentina, the survey covered only urban areas and in Panama it covered four areas categorized as urban, rural, hard-toreach rural, and indigenous.

${ }^{b}$ In Chile and Paraguay, the distribution variable was income per capita. 
TABLE 8. Results of median polishing for the percentages of persons who received health care, by quintile of household expenditure (or income) per capita and sex, for three age groups in 11 countries of Latin America

\begin{tabular}{|c|c|c|c|c|c|c|}
\hline & \multicolumn{5}{|c|}{ Children } & \\
\hline & 1 & 2 & 3 & 4 & 5 & \\
\hline \multicolumn{7}{|l|}{ Boys } \\
\hline Argentina ${ }^{a}$ & 32.3 & 15.1 & 0.0 & -4.1 & -10.1 & 20.6 \\
\hline Bolivia & 3.4 & 0.0 & 11.3 & -17.0 & -2.8 & -11.7 \\
\hline Brazil $^{b}$ & - & - & - & - & - & - \\
\hline Chile $^{a}$ & 23.3 & 10.1 & 0.0 & -5.1 & -14.6 & 21.6 \\
\hline Colombia & 0.0 & 0.6 & -4.7 & 3.4 & -3.8 & 16.9 \\
\hline Ecuador & 8.5 & 2.6 & 0.0 & -2.2 & 0.0 & -12.5 \\
\hline El Salvador & 5.3 & -1.1 & -7.7 & 0.0 & 1.9 & 8.0 \\
\hline Nicaragua & 7.9 & 0.8 & -14.9 & -13.5 & 0.0 & -21.5 \\
\hline Panama & 0.0 & 5.1 & 5.4 & -1.5 & -3.7 & -0.6 \\
\hline Paraguay ${ }^{a}$ & -7.2 & 0.0 & -1.7 & 13.1 & 6.6 & -11.1 \\
\hline \multirow[t]{2}{*}{ Peru } & 1.2 & -3.9 & 0.0 & -10.0 & 4.9 & -0.6 \\
\hline & 34.6 & 52.8 & 64.4 & 68.1 & 76.5 & \\
\hline \multicolumn{7}{|l|}{ Girls } \\
\hline Argentina $^{a}$ & 22.2 & 6.5 & 0.0 & -14.1 & -12.9 & 31.8 \\
\hline Bolivia & -0.6 & 0.0 & 4.7 & -6.7 & 10.0 & -9.3 \\
\hline Brazil $^{b}$ & - & - & - & - & - & - \\
\hline Chile $^{a}$ & 26.7 & 15.0 & 0.0 & -8.1 & -5.9 & 18.3 \\
\hline Colombia & 8.3 & 10.6 & -0.9 & -1.3 & 0.0 & 14.2 \\
\hline Ecuador & 0.7 & 0.0 & -2.1 & 0.3 & -1.7 & -13.1 \\
\hline El Salvador & 5.5 & 0.0 & -1.2 & -4.4 & 3.0 & 8.3 \\
\hline Nicaragua & 6.6 & 1.3 & -6.1 & -22.2 & 0.0 & -23.5 \\
\hline Panama & 6.5 & 8.0 & 0.0 & -5.1 & -7.4 & -0.7 \\
\hline Paraguaya & -15.4 & -12.1 & 1.3 & 3.0 & 0.0 & -0.6 \\
\hline \multirow[t]{4}{*}{ Peru } & 0.0 & -1.5 & 0.9 & 3.5 & -3.3 & -5.8 \\
\hline & 34.9 & 49.2 & 58.7 & 71.8 & 74.5 & \\
\hline & \multicolumn{6}{|c|}{ Adults } \\
\hline & 1 & 2 & 3 & 4 & 5 & \\
\hline \multicolumn{7}{|l|}{ Men } \\
\hline Argentina ${ }^{a}$ & 15.9 & 6.2 & 0.0 & -5.8 & -11.9 & 15.2 \\
\hline Bolivia & -2.4 & 0.0 & 4.4 & -20.3 & 0.4 & -0.4 \\
\hline Brazilb & 0.0 & 5.9 & -12.8 & -5.0 & 3.7 & 14.6 \\
\hline Chile $^{a}$ & 10.3 & 3.8 & -2.2 & 0.0 & -3.1 & 19.7 \\
\hline Colombia & 7.9 & 2.2 & -1.4 & -0.2 & 0.0 & 19.3 \\
\hline Ecuador & 11.3 & 9.2 & -14.5 & 0.0 & 0.0 & -11.3 \\
\hline El Salvador & 3.5 & 0.0 & -9.5 & -1.0 & 1.3 & -10.2 \\
\hline Nicaragua & 5.9 & 5.6 & -6.9 & -3.9 & 0.0 & -13.1 \\
\hline Panama & 3.1 & 1.8 & -1.0 & 0.0 & -7.8 & 1.0 \\
\hline Paraguaya & -6.2 & 0.0 & -5.5 & 0.0 & 2.4 & 0.0 \\
\hline \multirow[t]{2}{*}{ Peru } & 16.4 & 8.3 & -6.4 & 0.0 & -5.1 & -22.9 \\
\hline & 29.2 & 41.5 & 60.0 & 60.0 & 62.1 & \\
\hline \multicolumn{7}{|l|}{ Women } \\
\hline Argentina $^{a}$ & 17.0 & 9.3 & 0.0 & -4.8 & -4.9 & 22.3 \\
\hline Bolivia & -3.2 & -2.1 & 4.7 & 0.0 & 12.4 & -3.3 \\
\hline Brazilb & 11.5 & 0.0 & -17.1 & 4.9 & -9.3 & 10.5 \\
\hline Chile $^{a}$ & 19.5 & 6.8 & 0.0 & -6.2 & -6.2 & 19.2 \\
\hline Colombia & 12.4 & 0.0 & 3.0 & -2.3 & -7.9 & 28.9 \\
\hline Ecuador & 8.9 & 0.0 & -7.1 & 0.6 & -5.7 & -9.0 \\
\hline El Salvador & 0.0 & 0.0 & -1.0 & 0.0 & -5.2 & 0.0 \\
\hline Nicaragua & 8.0 & 0.3 & 0.0 & -2.5 & -5.5 & -10.5 \\
\hline Panama & 0.0 & 3.1 & 2.0 & -6.2 & -11.2 & 6.0 \\
\hline Paraguaya & -0.5 & -2.7 & 0.0 & 5.0 & 0.0 & 0.0 \\
\hline \multirow[t]{2}{*}{ Peru } & 5.5 & 0.3 & 0.0 & -3.3 & -9.5 & -11.4 \\
\hline & 31.5 & 45.2 & 52.5 & 59.0 & 66.0 & \\
\hline
\end{tabular}


TABLE 8. (Continued)

\begin{tabular}{|c|c|c|c|c|c|c|}
\hline & \multicolumn{5}{|c|}{ Older Adults } & \\
\hline & 1 & 2 & 3 & 4 & 5 & \\
\hline \multicolumn{7}{|l|}{ Men } \\
\hline Argentina $^{a}$ & 15.6 & 12.3 & -0.4 & 0.0 & -2.8 & 19.9 \\
\hline Bolivia & -3.8 & -1.3 & 3.9 & 0.0 & 11.3 & -4.9 \\
\hline \multicolumn{7}{|l|}{ Brazil $^{b}$} \\
\hline Chile $^{a}$ & 12.4 & 8.2 & 0.0 & -6.1 & -5.5 & 25.5 \\
\hline Colombia & 0.0 & 9.3 & -3.0 & 9.1 & -1.0 & 21.8 \\
\hline Ecuador & 2.4 & 0.0 & -6.0 & 1.0 & -3.5 & -2.4 \\
\hline El Salvador & 6.7 & 0.0 & -1.5 & -1.6 & 18.3 & -16.0 \\
\hline Nicaragua & 12.6 & 10.3 & -8.9 & 0.0 & -6.3 & -14.1 \\
\hline Panama & -14.7 & 0.0 & 4.8 & 1.2 & -22.9 & 14.7 \\
\hline Paraguaya & -4.9 & 1.5 & 0.0 & 0.4 & -3.3 & 0.9 \\
\hline \multirow[t]{2}{*}{ Peru } & 3.7 & -7.2 & -6.8 & 1.7 & 0.0 & -3.0 \\
\hline & 35.5 & 46.8 & 59.0 & 62.1 & 69.4 & \\
\hline \multicolumn{7}{|l|}{ Women } \\
\hline Argentina ${ }^{a}$ & 21.5 & 18.4 & 0.0 & -4.8 & -11.2 & 21.5 \\
\hline Bolivia & -7.5 & 1.0 & 3.7 & -7.1 & 0.0 & -4.3 \\
\hline \multicolumn{7}{|l|}{ Brazil $^{b}$} \\
\hline Chile $^{a}$ & 14.0 & 12.9 & 0.0 & -2.8 & -13.2 & 23.0 \\
\hline Colombia & 5.9 & 10.8 & -1.7 & 0.0 & -7.7 & 23.5 \\
\hline Ecuador & 2.2 & 5.3 & -12.8 & 0.0 & -3.2 & -4.8 \\
\hline El Salvador & 0.0 & 1.3 & -5.7 & -8.1 & 1.8 & -4.9 \\
\hline Nicaragua & 10.0 & 7.9 & 0.0 & -2.8 & -6.7 & -16.0 \\
\hline Panama & -4.9 & 3.9 & 3.1 & 0.0 & -13.8 & 17.0 \\
\hline Paraguay ${ }^{a}$ & 0.0 & -3.1 & -2.1 & 2.2 & 7.5 & 2.6 \\
\hline \multirow[t]{2}{*}{ Peru } & -1.7 & 5.1 & 1.3 & -1.7 & 0.0 & -12.4 \\
\hline & 40.0 & 45.1 & 60.0 & 66.8 & 76.6 & \\
\hline
\end{tabular}

a The sample size in Brazil was not large enough to study this age group.

b In Argentina, Chile and Paraguay, the distribution variable was income per capita.

and 6), yet children who sought health care in Peru were approximately $17 \%$ fewer than in Colombia. If one computes the percentage of children in the entire population for whom health care was sought, the figures from both countries are nearly identical for all five quintiles. They are $9.2 \%$ in Colombia and $7.4 \%$ in Peru in the first expenditure quintile; $12.6 \%$ and $11.6 \%$, respectively, in the second quintile; $15.6 \%$ and 13.2 in the third quintile, 16.2 and 20.3 in the fourth, and 21.9 and 18.2 in the fifth. They were almost invariably higher in Colombia, but never by more than $2 \%$ or $3 \%$.

Among children, practically no differences were detected between boys and girls in any of the countries in terms of utilization of health care. The only exceptions were Argentina and Paraguay, where, on average, about $10 \%$ more girls than boys sought health care, and in Peru, where the percentages for girls were somewhat lower than for boys.

In all countries except Paraguay, proportionately fewer adults than children sought health care for their reported health problems. There was also less variation among adults than children in all countries. With the exception of Brazil, health care was sought by higher percentages of women than men, on average, although health care usage among men and women was very similar in Bolivia, Chile, Colombia, and Ecuador.

The percentages of individuals who sought health care was higher among older adults, as was to be expected, and there was small variability from one country to another. With the exception of Peru, percentages of health care use were on average higher for women than men among older adults. They were almost identical in Bolivia and Ecuador. Although in a few countries percentages were very similar in urban and rural areas, they were almost always higher in urban areas among individuals of either sex. The only exception was Jamaica, where the number of women who sought health care in rural areas was almost $10 \%$ higher than in urban areas.

The percentage of people who sought health care in the upper quintile of household expenditure (or income) per capita was on average close 
TABLE 9. Results of median polishing for the percentages of persons in urban and rural areas who received health care, by quintile of expenditure (or income) per capita and sex, in nine $e^{\mathrm{a}}$ countries of Latin America

\begin{tabular}{|c|c|c|c|c|c|c|}
\hline & \multicolumn{5}{|c|}{ Urban Area } & \\
\hline & 1 & 2 & 3 & 4 & 5 & \\
\hline \multicolumn{7}{|l|}{ Men } \\
\hline Bolivia & 4.4 & 3.0 & -2.6 & -6.1 & 0.0 & 6.1 \\
\hline Brazil & 0.0 & 6.3 & -8.0 & 6.3 & -6.9 & 8.2 \\
\hline Chile & 11.4 & 10.0 & 0.0 & -0.5 & -5.4 & 17.8 \\
\hline Colombia & -8.4 & 1.5 & 0.0 & 4.5 & -6.1 & 25.1 \\
\hline Ecuador & 1.2 & 5.9 & -7.9 & 0.0 & -4.1 & -5.9 \\
\hline El Salvador & 0.0 & -1.8 & -6.1 & 0.2 & 0.0 & 0.0 \\
\hline Nicaragua & -1.4 & 11.5 & 0.0 & -0.5 & 0.9 & -19.9 \\
\hline Paraguay ${ }^{b}$ & -12.2 & -5.9 & 2.6 & 1.8 & 0.0 & -2.6 \\
\hline \multirow[t]{2}{*}{ Peru } & -0.9 & 7.6 & -0.1 & 3.6 & 0.0 & -15.9 \\
\hline & 42.3 & 46.4 & 56.9 & 57.4 & 66.0 & \\
\hline \multicolumn{7}{|l|}{ Women } \\
\hline Bolivia & -8.0 & -2.4 & 1.9 & 0.0 & 5.4 & 0.0 \\
\hline Brazil & 15.9 & 11.5 & -7.8 & 0.0 & -6.5 & 7.8 \\
\hline Chile $^{b}$ & 19.9 & 14.8 & 0.0 & -3.9 & -12.3 & 20.0 \\
\hline Colombia & 11.4 & 12.0 & 0.0 & -0.7 & -13.4 & 28.0 \\
\hline Ecuador & 6.6 & 5.4 & -10.7 & 0.0 & -10.3 & -6.6 \\
\hline El Salvador & 1.8 & 10.9 & -0.9 & 0.0 & -4.7 & -1.2 \\
\hline Nicaragua & 4.2 & 8.7 & -2.3 & 0.0 & -6.7 & -16.7 \\
\hline Paraguay ${ }^{b}$ & -0.9 & 0.0 & 3.8 & 8.0 & 0.0 & 0.0 \\
\hline \multirow[t]{2}{*}{ Peru } & -3.6 & 10.4 & 0.0 & 0.6 & -8.8 & -10.8 \\
\hline & 34.5 & 40.0 & 55.0 & 60.7 & 74.4 & \\
\hline
\end{tabular}

\begin{tabular}{|c|c|c|c|c|c|c|}
\hline & & & iural Are & & & \\
\hline & 1 & 2 & 3 & 4 & 5 & \\
\hline Men & & & & & & \\
\hline Bolivia & -0.9 & 0.0 & 14.2 & -5.4 & $15.2 \mid$ & -1.5 \\
\hline Brazil & 0.8 & 0.0 & -6.2 & -4.3 & 3.5 & 13.8 \\
\hline Chileb & 10.9 & 9.3 & 0.0 & -5.8 & -18.3 & 18.3 \\
\hline Colombia & 0.0 & 5.0 & -4.9 & -1.0 & 0.1 & 22.5 \\
\hline Ecuador & 0.0 & 1.3 & -5.7 & -0.6 & 1.2 & 0.6 \\
\hline El Salvador & 3.1 & 3.1 & 0.0 & -1.4 & -1.0 & -3.1 \\
\hline Nicaragua & 6.9 & 9.9 & 0.0 & -5.1 & -1.0 & -11.4 \\
\hline Paraguay ${ }^{b}$ & -8.8 & 0.0 & 0.5 & 4.9 & -10.5 & -0.5 \\
\hline Peru & 8.6 & 0.0 & 1.5 & -1.4 & -13.5 & -8.6 \\
\hline & 28.5 & 35.5 & 45.4 & 53.5 & 61.4 & \\
\hline Women & & & & & & \\
\hline Bolivia & -3.2 & 0.0 & 5.1 & -5.9 & $6.7 \|$ & 0.0 \\
\hline Brazil & -0.9 & 0.0 & 2.1 & -5.8 & 26.1 & 9.4 \\
\hline Chile ${ }^{b}$ & 14.7 & 8.8 & 0.0 & -3.2 & -14.7 & 21.5 \\
\hline Colombia & 9.9 & 0.4 & 0.0 & -2.8 & -5.8 & 25.3 \\
\hline Ecuador & 2.5 & 0.0 & -6.4 & 2.4 & -10.0 & -2.5 \\
\hline El Salvador & 0.9 & 0.0 & -5.1 & 3.9 & -5.7 & 4.5 \\
\hline Nicaragua & 11.9 & 7.4 & 0.0 & -3.8 & -0.8 & -13.7 \\
\hline Paraguay ${ }^{b}$ & -4.4 & -3.9 & 0.0 & 0.0 & 0.0 & 0.0 \\
\hline Peru & 5.0 & -2.3 & 1.2 & 0.0 & -20.6 & -8.3 \\
\hline & 28.8 & 40.3 & 51.7 & 55.5 & 64.5 & \\
\hline
\end{tabular}

a In Argentina, the survey covered only urban areas and in Panama it covered four areas categorized as urban, rural, hard-toreach rural, and indigenous.

${ }^{b}$ In Chile and Paraguay, the distribution variable was income per capita. 
to twice as large as in the lowest quintile of expenditure (or income) per capita. This was true for all age groups in both urban and rural areas, and for both sexes. Considering the fact that the percentage of individuals who reported health problems may be underreported in the lower quintiles, there may be some very large inequities in health care utilization across countries, for all areas and age groups.

Health care utilization was not invariably twice as high in the upper expenditure or income quintile than in the lowest quintile. The two main examples are those of Argentina and Chile (see the residuals in Table 7) for all age groups, and Chile in both urban and rural areas; in these countries the inequalities were very small for children and adults but somewhat larger for older adults (Table 4). The other exception is Nicaragua, where the percentages for older adults of either sex were lower for all quintiles.

The graphs in Figures 1, 2, and 3 show the results of median polishing for health care among children, adults, and older adults, respectively. The graphs resulting from the median polishing represent the combined "effects" of rows and columns in the original table, which in this particular case relate to countries and quintiles, respectively. The value at one of the vertices is the "fitted" value for that country and quintile. Between the sections for boys and girls and men and women there is a box and a whisker plot $(17,18)$ of the residuals. The values represented by small circles are the ones that could be considered "outliers", exceptionally large values.

In general, the percentage of individuals who sought health care was greater among women than men in all age groups, although the difference was more marked in the adult age group, possibly on account of the reproductive aspects of women's health in this age bracket. There are exceptions to this in some countries. The graphs illustrating the results of median polishing should not be interpreted without taking into account the large residuals. The three countries with the highest average percentages

FIGURE 1. Results of median polishing for the percentage of children who received health care among those who were reported as having had a health problem, by sex and quintile of household expenditure per capita, for 11 countries of Latin America, 1997-1999

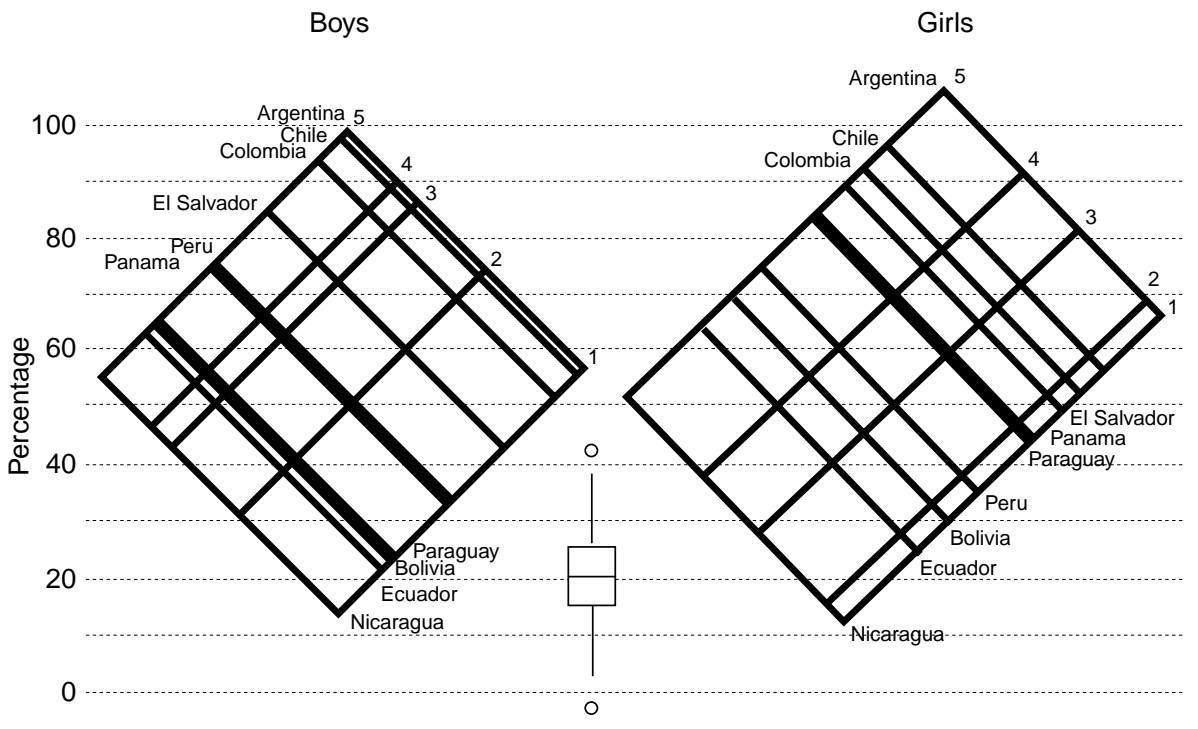

FIGURE 2. Results of median polishing for the percentage of adults who received health care among those who were reported as having had a health problem, by sex and quintile of household expenditure per capita, for 11 countries of Latin America, 1997-1999

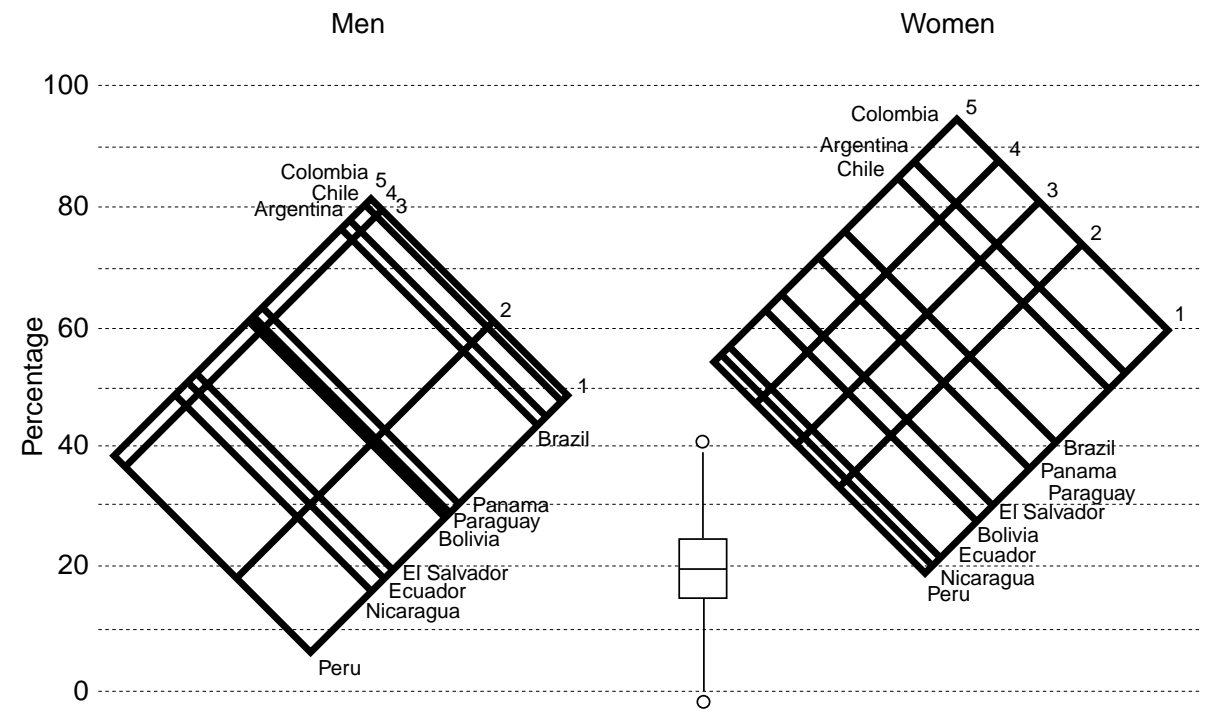

of individuals who sought health care, for all age groups and both sexes, among those who reported a health problem were Argentina, Chile, and Colombia. These countries were also the ones with the smallest inequalities across economic strata, particularly among children.

The graphs in Figure 4 represent the results of median polishing for urban and rural areas and all age groups in nine of the 12 countries studied. (Ja- 
FIGURE 3. Results of median polishing for the percentage of older adults who received health care among those who were reported as having had a health problem, by sex and quintile of household expenditure per capita, for 11 countries of Latin America, 1997-1999

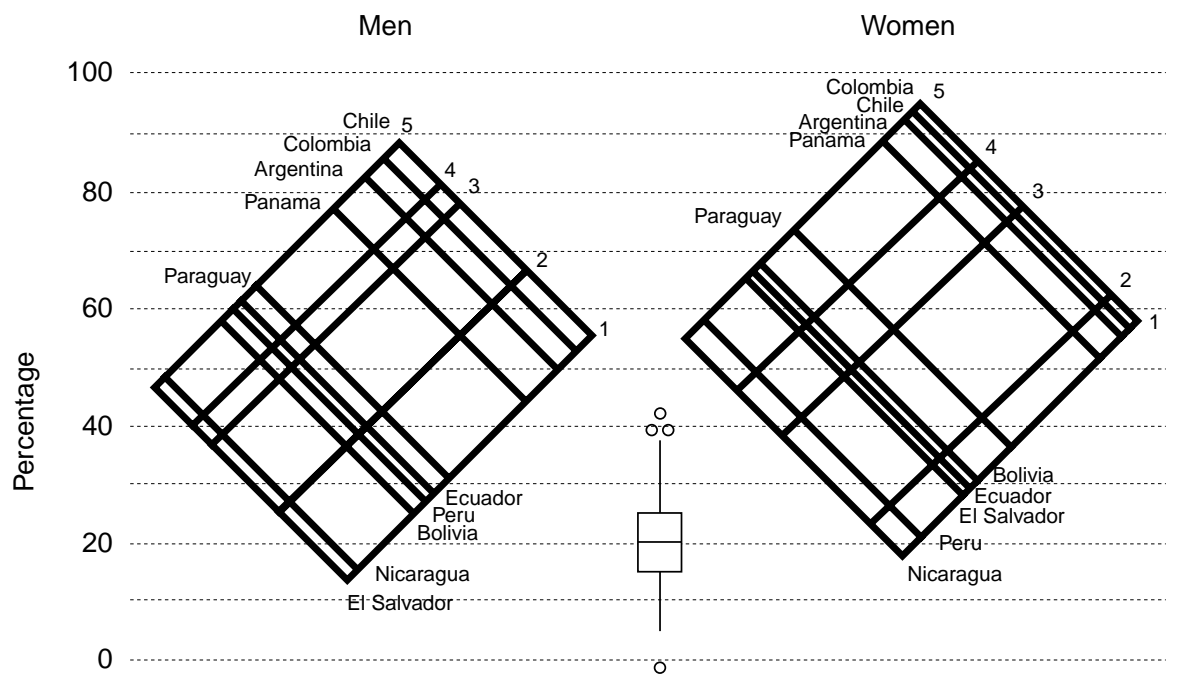

urban areas, the percentages of women who seek health care are lower than the percentages of men.

- In urban areas, the gradient for seeking care is smaller for men than for women.

A set of recommendations and conclusions:

- The questions about self-reported health problems should be simplified and improved. Research should be done on ways of eliciting responses that are less dependent on economic status and cultural background (19-21).

- The response categories for the question regarding a health problem should be extended from simply "yes" and "no" to include specific illnesses and conditions. There is increasing evidence that, at least for children, the expected economic gradient is found when questions are asked about specific problems, such as diarrhea and upper respiratory tract infections.

- The questions about seeking care should also be improved. The reference period for both questions should be very precise and not very long.

- The response categories for seeking care should always make it possible to tell when care was sought in the formal health system and when it was not. It would also be useful to know the type of establishment where care was sought. This information is available in only a few of the surveys.

- Notwithstanding all the problems with the questions and response categories, the surveys are an invaluable source of data for studying inequalities in health. These data should be used to study in depth the relationship between these inequalities and their determinants. Most of the published studies on health inequalities present only geographical or large area inequalities, without addressing the development of models for specific outcomes, which would make it possible to devise policies to reduce those inequalities. rize the findings of this descriptive, exploratory study: health care is higher, in general, than the percentage of men, especially among adults, which may be attributed in part to the reproductive aspects of women's health.

- For the two lowest quintiles of expenditure (income) per capita in 
FIGURE 4. Results of median polishing for the percentages of the urban and rural population who received health care among those who were reported as having had a health problem, by sex and quintile of household expenditure per capita, in nine countries of Latin America, 1997-1999

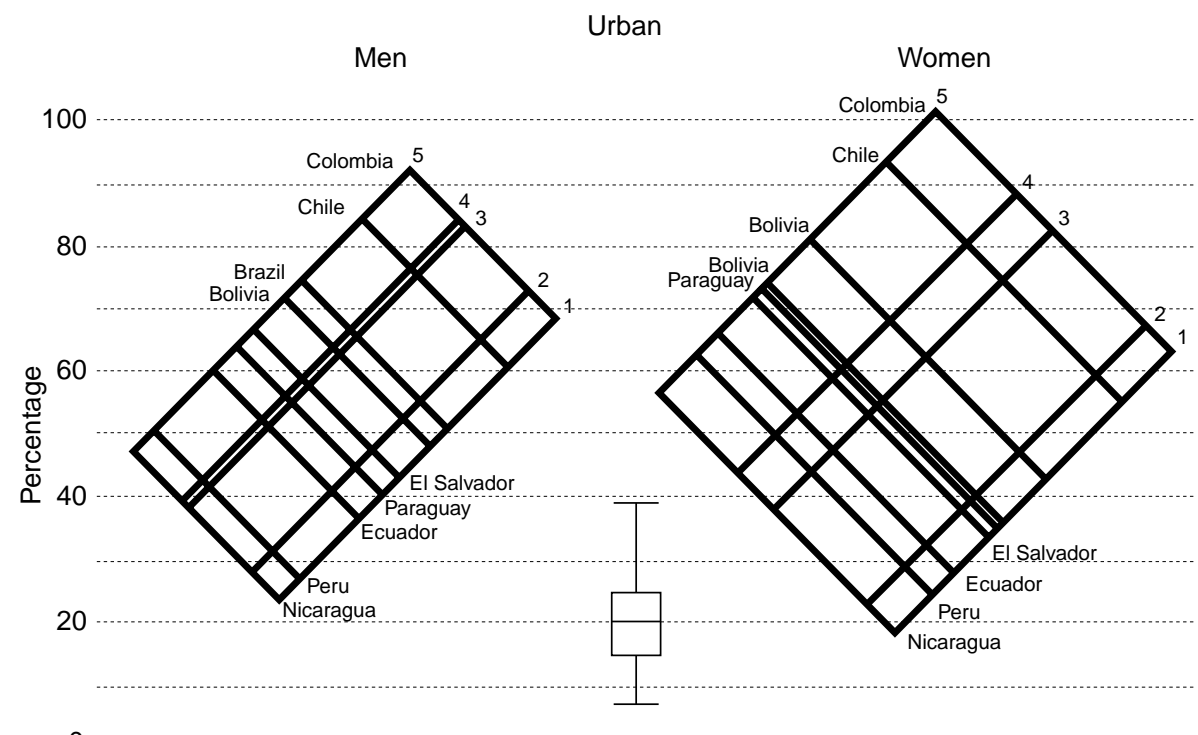

0

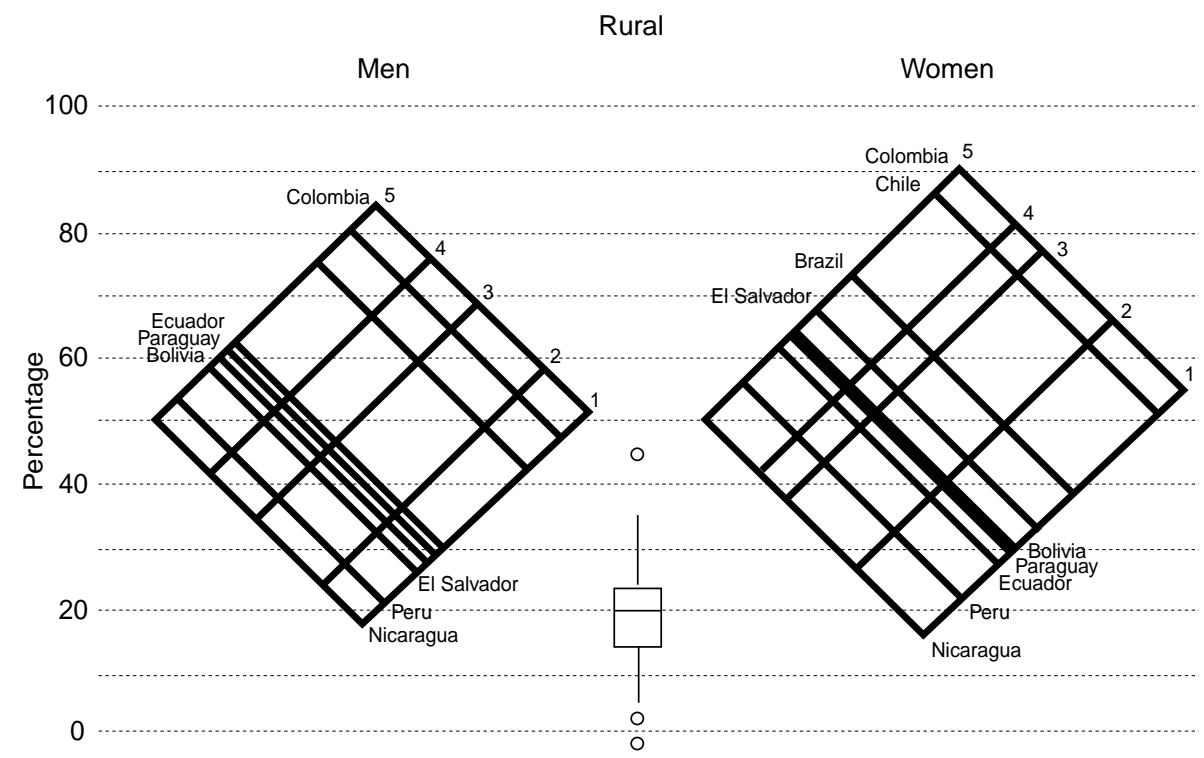

The results presented in this paper are a first step in trying to obtain answers to some of the questions raised by Rosemberg and Andersson (22) in the discussion section of their paper: "What are the dimensions of social exclusion in health in Latin America and the Caribbean?" and, more impor- tantly, "Who are the excluded persons?" in terms of their demographic and socioeconomic characteristics and place of residence. By improving the instruments for collecting data (questionnaires) and by broadening the analyses, it will be possible to reach a much better understanding of the real dimensions of the problem and of its social and economic determinants. This knowledge, combined with an understanding of each country's health system, will make it possible to propose better policy alternatives within the health sector reform processes so as to increase health coverage and access 
to health care and to bring utilization closer to need (23).

This paper also points to an important methodological recommendation. Due to the different patterns of economic gradients among different age groups and among males and females, the practice of standardization used in constructing concentration curves and in computing concentration indices should be avoided (24-26).

Acknowledgments. Most of the information used in preparing this paper was gathered within the context of two separate projects developed by PAHO's Program on Public Policy and Health, with partial support from the Research Coordination Program of the Division of Health and Human Development. One of the projects, namely the production of summary data on health inequalities, was carried out by the Department of Social Sciences of the University of Chile and the Department of Economics of the University of The Andes in Colombia. The second one was a multi-center research project carried out in Bolivia, Brazil, Colombia, and Peru, respectively, by researchers at the Unit of Analysis of Economic and Social Policies (UDAPE) of the Ministry of Finance in La Paz, Bolivia; the Department of Preventive and Social Medicine of the Federal University of Pelotas, Brazil; the Department of Economics of the University of the Andes in Santa Fe de Bogota, Colombia; and the Analysis for Development Group, a think tank in Lima, Peru.

\section{REFERENCES}

1. Casas JA, Dachs JN, Bambas A. Health disparities in Latin America and the Caribbean: the role of social and economic determinants. In: Equity and health: views from the Pan American Sanitary Bureau. Washington, D.C.: Pan American Health Organization; 2001. (Occasional Publication No. 8). http://www. paho.org/English/DBI/Op08_03.pdf (02/ 05/2002)

2. Paim JS, Costa MCN. Decline and unevenness of infant mortality in Salvador, Brazil, 19801988. Bull Pan Am Health Org 1993;27(1): $1-14$.

3. Victora C, Vaughan JP, Barros F, Silva A, Tomasi E. Explaining trends in inequities: evidence from Brazilian child health studies. Lancet 2000;356(September 23):1093-1098.

4. Ferrer M. Health modules in household surveys in Latin America and the Caribbean: an analysis of recent questionnaires. Washington, D.C.: Pan American Health Organization; 2000. (Technical Report Series No. 72, HDP/ HD).

5. Ravallion M. Poverty comparisons. Chur, Switzerland: Harwood Academic Publishers; 1994.

6. Sadana R, Mathers CD, Lopez AD, Murray $\mathrm{CJL}$, Iburg K. Comparative analyses of more than 50 household surveys on health status. Geneva: World Health Organization; 2000. (GPE Discussion Paper Series No. 15).

7. Foucault M. The birth of the clinic: an archaeology of medical preparation. New York: Vintage Books, Inc.; 1963.

8. Kleinman A, Eisenberg L, Good B. Culture, illness and care: clinical lessons from anthropologic and cross- cultural research. Ann Intern Med 1978;88:251-258.
9. Nunnally JC, Bernstein IR. Psychometric theory. Third edition. New York: McGraw Hill; 1994.

10. Mackenbach JP, Looman CWN, Van der Meer JBW. Differences in misreporting of chronic conditions, by level of education: the effect on inequalities in prevalence rates. Am J Public Health 1996;86(5):706-711.

11. Harlow DE, Linet MS. Agreement between questionnaire data and medical records. Am J Epidemiol 1989;129(2):233-248.

12. Sen A. Objectivity and position: assessment of health and well-being. In: Chen LC, Kleiman A, Ware NC, eds. Health and social change in international perspective. Boston: Harvard School of Public Health; 1994. Pp. 115-128. (Harvard Series on Population and International Health).

13. Kind P, Dolan P, Gudex C, Williams A. Variations in population health status: results from a United Kingdom national questionnaire survey. BMJ. 1998;316(7 March):736-741.

14. Heliovaara M, Aromaa A, Klaukka T. Reliability and validity of interview data on chronic diseases. J Clin Epidemiol 1993; 46(2):181-191.

15. Deaton A. The analysis of household surveys: a microeconometric approach to development policy. Baltimore: The Johns Hopkins University Press; 1997.

16. Pan American Health Organization. Summarysheets of inequalities in health. Washington, D.C.: PAHO; 2001.

17. Tukey JW. Exploratory data analysis. Reading, Mass.: Addison Wesley; 1977.

18. Velleman PF, Hoaglin DC. Applications, basics, and computing of exploratory data analysis. Boston, Mass.: Duxbury Press; 1981.
19. Grosh M, Glewwe P, eds. Designing household survey questionnaires for developing countries: lessons from 15 years of LSMS experience. Washington, D.C: World Bank; 2000.

20. Eurostat. European Community Household Panel (ECHP): methods. Volume I. Luxembourg: Office for Publications of the European Communities; 1996.

21. De Bruin A, Picavet HSJ, Nossikov A. Health interview surveys: towards international harmonization of methods and instruments. Copenhagen: World Health Organization; 1996.

22. Rosemberg H, Andersson B. Repensar la protección social en salud en América Latina y el Caribe. Pan Am J Public Health 2000;8(1/2): 118-125.

23. Mesa-Lago C. Social assistance on pensions and health care for the poor in Latin America and the Caribbean. Chapter 8. In: Lustig N, ed. Shielding the poor: social protection in the developing world. Washington, D.C.: Brookings Institution Press and Inter-American Development Bank;2001.

24. Van Doerslaer E, Wagstaff A, Rutten F, eds. Equity in the finance and delivery of health care. New York: Oxford University Press; 1993.

25. Van Doerslaer E, Wagstaff A. Inequity in the delivery of health care: methods and results for Jamaica. In: Investment in health: social and economic results. Washington, D.C.: Pan American Health Organization; 2000.

26. Choi BCK, de Guia NA, Walshet P. Look before you leap: stratify before you standardize. Am J Epidemiol 1999;149(12):1087-1095. 


\section{APPENDIX 1: QUESTIONS USED}

The question on self-reported illness or injury ("health problem")

Argentina: The question is number S1 ("health" section, for all household members). Question S1: In the past 30 days has (. . .name. . .) had any sickness, illness or accident? The response categories are 1) Yes; 2) No.

The yes answer was considered a health problem.

Bolivia: The question is number S311, section 3 ("health" section, for all household members).

Question S311: In the last 4 weeks has (. . .name. . .) 1) felt ill?; 2) had an accident, burn, or a cut?;

3) been healthy?

Categories 1 and 2 were considered a health problem.

Brazil: The question is number 22, section 5 ("health" section, for all household members). Question 22: Did (. . .name. . .) have any health problem over the past 30 days? The response categories are 1) Yes; 2) No.

Category 1 was considered a health problem.

Chile: The question is number 5 , section IV ("health" section, for all household members).

Question 5: In the past three months has (. . .name. . .) had an illness or accident (or pregnancy)?

The response categories are: 1) Yes, with medical care; 2) Yes, without care. It wasn't necessary; 3) Yes, without care; (he/she) used household medication or alternative medicine; 4) Yes, without care; there were problems (difficulties) to be attended; 5) Yes, without care, for other reasons (specify); 6) Didn't have any illness or accident.

The first five categories were considered a health problem.

Colombia: The question is number 18 of chapter $F$ (for all household members).

Question 18: In the past 30 days has (. . .name. . .) had any sickness, accident, dental problem, or any other health problem? The response categories are 1) Yes; 2) No; 3) Does not know.

The yes answer was considered a health problem or an accident.

Ecuador: The question is number 31, part $C$ (presence of illness, for all members of the household). Question 31: During the past month (. . .name. . .) has had any illness, accident, burn, toothache or earache or any other illness, even if it was brief? The categories of response were: 1) Yes; 2) No.

The yes answer was considered a health problem.

El Salvador: The question is number 6 , section 6 ("health" section, for all members of the household). Question 3: During the past month has (. . .name. . .) had any illness, a wound tended (curación), an accident, or has he/she been injured in any act of delinquency? The response categories are: 1) IIIness; 2) an animal bite tended (curación); 3) another type of pound tended (curaciones); 4) accident; 5) crime-related injury; 6) Did not have any.

The first five categories were considered a health problem.

Jamaica: Questions 2 and 3, part A ("health" section, for all family members) were used.

Question 2: Have you had any injury during the past 4 weeks? For example, due to an accident at your workplace, gunshot, stabbing, accidental fall, or other injury? The response categories are: 1) Yes, due to motor vehicle accident; 2) Yes, accident at workplace; 3) Yes, was shot; 4) Yes, was stabbed; 5) Yes, other accident; 6) Yes, other; 7) None.

Question 3: Have you had any illness other than one due to injury during the past 4 weeks? For example, have you had a cold, diarrhea, or any other illness? The response categories are: 1) Yes; 2) No. The first six categories of question 2 and the first category of question 3 were considered a health problem.

Nicaragua: The question is number 23 , section 3 , part C ("presence and control of diseases", for all household members).

Question 3: Over the past month has (. . .name. . .) had any health problem such as: The response categories are: 1) Cough, cold, or any respiratory ailment; 2) Measles or another eruptive disease; 3) An accident; 4) Diarrhea for persons over 6 years of age; 5) Another disease or several of the previous ones; 6) Was healthy.

The first five categories were considered a health problem.

Panama: The question is number 30 , section 3 ("health" section, part B, for all member of the household 5 years of age or older).

Question 30: Over the past month, did (. . .name. . .) have any illness, accident (burn, fracture, fall, etc.) or ailment (toothache, headache, earache, etc.), however brief?

The response categories are: 1) Yes; 2) No.

The yes answer was considered a health problem.

Paraguay: The question is number 3 , section 4, ("health" section, for all household members). Question 3: During the past three months has (. . . name. . .) been sick or suffered an accident? The response categories are: 1) Yes, was sick; 2) Yes, had an accident; 3) No, (he/she) was healthy.

The first two categories were considered a health problem.

Peru: The question is number 2, section 4, ("health" section, part A, for all household members). Question 2: During the past four weeks has (. . .name. . .) been ill, had an accident, or had any symptom or ailment? 
The response categories are: 1) Yes, ailment; 2) Yes, illness; 3) Yes, accident; 4) No, nothing.

The first three categories were considered a health problem.

The question on seeking health care

Argentina: The question is number S2 ("health" section, for all members of the household, applied to all persons who responded yes to question $\mathrm{S} 1$ above).

Question S2: Whom did (. . . name. . .) consult for this sickness, illness, or accident? The response categories are: 1) A physician, dentist, or psychologist; 2) A nurse; 3) A pharmacist; 4) A traditional healer; 5) A neighbor, friend or family member; 6) Somebody else; 7) Didn't consult anybody.

Categories 1 and 2 were considered health care.

Bolivia: Two questions had to be considered, numbers S312 and S313, section 3 ("health" section, for all household members, part B, access to health services). Question S312 applied to all persons for whom the answer to S311 (see above) was 1 or 2 and question S313 was asked for all persons for whom the answer to $\mathrm{S} 312$ was from 1 to 8 .

Question S312: Where was (. . .name. . .) seen for this illness or accident? The response categories are 1) Public hospital; 2) Health center; 3) Health post; 4) Social security system facility; 5) Private clinic or private hospital; 6) Doctor's office; 7) Pharmacy; 8) At home; 9) No care.

Question S313: Who treated (. . .name. . .) due to this illness or accident? The response categories are: 1) Physician; 2) Nurse or nursing assistant; 3) Health promoter; 4) Traditional healer; 5) Pharmacist; 6) Somebody else; 7) Another member of the household.

Responses 1 through 8 in S312 and 1, 2, or 3 in S313 were considered health care.

Brazil: The questions are number 26 and 30, section 5 ("health" section, for all household members who answered yes to question 22 (see above) and also answered yes to question 24): Did (. . . name. . .) interrupted any of his/her usual activities due to this health problem?

Question 26: Did (. . .name. . .) seek care for this health problem? The response categories are 1) Yes; 2) No.

Question 30: Who treated (. . .name. . .)? The response categories are: 1) Physician; 2) Dentist; 3) Nurse; 4) Pharmacist; 5) Traditional healer (curandeiro); 6) Other.

The yes category in question 26 and in categories 1, 2, and 3 in question 30 were considered health care.

Chile: The question is the same as for reported illness or accident, number 5 , section IV, health module, for all household members (see above).

Category 1 was considered health care.

Colombia: The question is number 20 , chapter $\mathrm{F}$ (for all members of the household. It applied to all persons who answered yes to question number 18 above).

Question 20: To treat this health problem in the past 30 days what was the principal action taken? The response categories are: 1) Sought a professional or a health care facility (hospital, clinic, health center); 2) Sought a health promoter or a nurse; 3) Sought the pharmacist, drug store; 4) Sought a "tegua", empirical healer, herbist, traditional birth attendant; indigenous or traditional medicine; 5) Sought alternative therapies (homeopathy, acupuncture, flower essences, music therapy, etc.) 6) Used home remedies; 7) Self medication; 8) Nothing.

The first two categories were considered health care.

Ecuador: The question is number 35, section 3, part C, "presence of illness", for all persons in the household who answered yes to question 31 (see above).

Question 35: Due to the (. . . .illness, accident, etc. . .) that (. . .name. . .) had, did (. . .he/she. . .) 1) Visit or call a physician, nurse, or traditional healer; 2) go to the pharmacy to get medicine; 3) Medicate him/herself; 4) Take or receive "medicinal water"; 5) Didn't do anything; 6) Other (specify)?

Response category 1 was considered health care, although it is impossible to distinguish care by a physician or nurse from care by a traditional healer.

El Salvador: The question is number 5, section 6 ("health" section, for all members of the household). Question 5: Whom did (. . .name. . .) you chiefly consult for the most recent illness, accident, or injury due to delinquency in the past month? The response categories are: 1) Physician; 2) Nurse; 3) Health promoter; 4) Pharmacist; 5) Traditional birth attendant; 6) Dentist; 7) Traditional healer; 8) Family member or neighbor; 9) Medicated him/herself; 10) Nobody.

Categories 1, 2, 3, and 6 were considered health care.

Jamaica: The question is number 6 , part A ("health" section, for all members of the household).

Question 6: Has a doctor, nurse, pharmacist, midwife, healer, or any other health practitioner been visited during the past 4 weeks? The response categories are 1) Yes. and 2) No.

The yes response was considered health care, although it is not possible to know if a pharmacist or a traditional healer was sought.

Nicaragua: The question is number 25, section 3, part C ("presence and control of diseases," for all members of the household).

Question 25: Who was the person that (. . .name. . .) last consulted?

The response categories are: 1) Physician; 2) Nurse; 3) Nurse auxiliary; 4) Pharmacist; 5) Traditional birth attendant; 6) Traditional healer; 7) Community health worker (brigadista); 8) Other.

Categories 1, 2, 3, and 7 were considered health care. 
Panama: The question is number 34, section 3 ("health" section, part B, for all household members 5 years of age and older who answered yes to question 30) (see above).

Question 34: Whom did (. . .name. . .) consult over the past month when (. . .he/she. . .) was ill, had an accident, or had to go for follow-up? The response categories are: 1) Physician/ dentist/ gynecologist; 2) nurse/nursing assistant; 3) health assistant; 4) traditional healer/ witch; 5) pharmacist; 6) family members/other persons in the household/neighbor; 7) Medicated him/herself; 8) nobody; 9) other.

Response categories 1,2, and 3 were considered health care.

Paraguay: The question is number 7, section 4 ("health" section, part A, for all household members).

Question 7: Whom did (. . .name. . .) consult for the most recent illness or accident over the past three months? The response categories are: 1) Physician; 2) professional birth attendant; 3) traditional birth attendant (chaé); 4) nurse; 5) dentist; 6) pharmacist; 7) traditional healer; 8) family member or neighbor; 9) other.

Response categories 1, 2, 4, and 5 were considered health care.

Peru: The question is number 6 , section 4 ("health" section, part A, for all members of the household who answered yes to question 2) (see above).

Question 6: Did (. . .name. . .) consult anybody over the past four weeks because of this illness or accident? The response categories are: Yes . . . who attended the consultation? 1) Physician; 2) dentist; 3) obstetric nurse; 4) nurse; 5) health worker; 6) [health] promoter; 7) pharmacist; 8) birth attendant; 9) traditional healer; 10) other, whom? 11) No.

The first six categories were considered health care.

\section{APPENDIX 2: MEDIAN POLISHING}

The method known as median polishing was developed by John Tukey and first published in his book Exploratory Data Analysis in 1977. Essentially, it fits a two-way analysis of variance using medians instead of means. This non-linear process has the advantages of being very robust in the presence of potential outliers and, if further steps are followed, of making it possible to search for a non-additive model when the residuals indicate that the additive assumption is not satisfied. In the five instances in which the method was applied in this study, there was no indication that a non-additive model was at work, so that only the first steps of the method were performed.

The process is illustrated in Table A1 as applied to the data in Table 3, and the final results are presented in Table 5, which shows health care among children in 10 countries for each household expenditure (income) quintile.

TABLE A1. Results of median polishing for the percentages of persons who received health care, by quintiles of expenditure (income) per capita, for boys in 10 countries of Latin America

\begin{tabular}{|c|c|c|c|c|c|c|c|c|c|c|c|}
\hline Country & 1 & 2 & 3 & 4 & 5 & \multicolumn{6}{|c|}{ Boys } \\
\hline Bolivia & 26.4 & 41.1 & 64.0 & 39.4 & 62.1 & & & & & & \\
\hline Colombia & 51.5 & 70.3 & 76.6 & 88.4 & 89.6 & & & & & & \\
\hline Ecuador & 30.7 & 42.9 & 51.9 & 53.4 & 64.1 & & & & & & \\
\hline El Salvador & 47.9 & 59.8 & 64.8 & 76.1 & 86.5 & & & & & & \\
\hline Nicaragua & 21.0 & 32.0 & 28.0 & 33.0 & 55.0 & & & & & & \\
\hline \multirow[t]{3}{*}{ Peru } & 35.2 & 48.3 & 63.8 & 57.4 & 80.8 & & & & & & \\
\hline & 34.6 & 52.8 & 64.4 & 68.1 & 76.5 & & & & & & \\
\hline & & & & & & \multicolumn{6}{|c|}{ Residuals } \\
\hline Argentina $^{\mathrm{a}}$ & 52.9 & 35.7 & 20.6 & 16.4 & 10.5 & 20.6 & 32.3 & 15.13 & 0.00 & -4.15 & -10.12 \\
\hline Nicaragua & -13.6 & -20.8 & -36.4 & -35.1 & -21.5 & -21.5 & 7.93 & 0.75 & -14.88 & -13.53 & 0.00 \\
\hline Panama & -0.6 & 4.5 & 4.8 & -2.1 & -4.3 & -0.6 & 0.00 & 5.08 & 5.45 & -1.45 & -3.68 \\
\hline Paraguay ${ }^{a}$ & -18.3 & -11.1 & -12.8 & 2.0 & -4.4 & -11.1 & -7.23 & 0.00 & -1.73 & 13.12 & 6.65 \\
\hline Peru & 0.6 & -4.5 & -0.6 & -10.7 & 4.3 & -0.6 & 1.20 & -3.87 & 0.00 & -10.05 & 4.88 \\
\hline
\end{tabular}

${ }^{a}$ In Argentina, Chile, and Paraguay the distribution variable was income per capita. 
The first step (known as sweep) is to compute medians for each column. The median of the percentages in the column belonging to the first quintile (87.5 in Argentina, 26.4 in Bolivia, . . . 35.2 in Peru) is 34.6. The medians for the other columns are 52.8,64.4,68.1 and 76.5. This first sweep in completed by subtracting the median value from each original value. For example, the first figure in the second part of the table, which is 52.9, is the difference between 87.5 and 34.6. These are the "partial residuals" of the first sweep.

In the second sweep, medians are computed across rows in the new table. Figure 20.6 is the median of the "partial residuals" for Argentina: 52.9, 35.7, 20.6, 16.4, and 10.5. The next part of this step is to compute residuals once again by calculating the difference between the "partial residuals" and the median for each row. For example, the residual for Argentina in the first household expenditure quintile is $52.9-20.6=32.3$.

The medians across columns are called "column effects" (34.6, 52.8, 64.4, 68.1, and 76.5), and the medians across rows are called "row effects" $(20.6,-11.7,21.6,16.9,-12.5,8.0,-21.5,-0.6,-11.1$, and -0.6$)$. The figures shown in Table 5 are the results of these two sweeps, the row and column effects, and the residuals in the body of the table.

By adding the respective row and column effects and their residuals, the original value is obtained. For the first quintile in Argentina, for example, $32.3+20.6+34.6=87.5$.

Since the method is non-linear, a third and fourth sweep, similar to the first two, should be performed again on the final results. The effects for rows and columns are obtained by adding the results of their respective sweeps. When the data approximately satisfy the additive assumption-in other words, when there appear to be no systematic interactions between rows and columns-final results are very similar to those obtained with the first two sweeps. This was so in the case of the data analyzed in this study.

The results of the median polishing can then be illustrated by means of a graph. The first step is to build a network of vertical and horizontal lines (all equal in scale) for the values of the row and column effects. The resulting rectangle is then tilted $45^{\circ}$ and the scale adjusted so that the vertices represent the sums of the row and column effects. For example, the "fitted" value for boys, in the first quintile, in Argentina is $34.6+20.6=$ 55.2, which can be (approximately) read from the graph in Figure 1.

The easiest reference to read for a description of this methodology is chapter 8 in Veleman and Hoaglin (1981). Some computer statistical packages, including Minitab and SAS, have pre-programmed options for performing median polishing, and the procedure is also pre-programmed in S-plus language. The user-written procedure T2WAY5 makes it possible to perform it with STATA.

RESUMEN Objetivo. Explorar y describir las desigualdades detectadas a partir de la autonotificación de problemas de salud y de la búsqueda de atención sanitaria en 12 países de América Latina y el Caribe.

Métodos. Se analizan las preguntas sobre los problemas de salud y la búsqueda de atención en encuestas de hogares de tipo general y se describen las desigualdades correspondientes de acuerdo con quintiles de gasto (o ingreso) doméstico per cápita, sexo, grupo de edad (niños, adultos y adultos mayores) y área urbana o rural. En el caso de las personas que buscaron atención de salud, se aplica la técnica de pulimiento de medianas por nivel económico y sexo para los tres grupos de edad.

Resultados. Aun cuando el trabajo es exploratorio y descriptivo, los resultados muestran en los países estudiados la existencia de importantes gradientes en la utilización de servicios de salud según nivel económico, y la presencia de diferencias generalmente pequeñas entre hombres y mujeres, con algunas excepciones en los estratos económicos más bajos en áreas urbanas.

Conclusiones. Las desigualdades detectadas a partir de la autonotificación de problemas de salud son muy pequeñas entre personas de diferente nivel económico y los problemas suelen ser más frecuentes entre las mujeres que entre los hombres. Esto se debe posiblemente a diferencias culturales y sociales en la percepción de la salud. Las desigualdades en la búsqueda de atención son grandes en la mayoría de los países estudiados. Es muy importante que se desarrollen proyectos regionales encaminados a mejorar las preguntas para la autonotificación de problemas de salud con el fin de poder estudiar a fondo los factores que determinan las desigualdades en el ámbito sanitario. Los autores concluyen que debido a que los gradientes económicos muestran patrones diferentes en los distintos grupos de edad y en hombres y mujeres, los datos no deben estandarizarse a la hora de derivar curvas de concentración y calcular los índices de concentración. Al final hay una lista de recomendaciones sobre cómo mejorar estas fuentes de datos. Pese a sus deficiencias, las encuestas de hogares nos ayudan a entender las complejidades de las desigualdades de salud en estos países. 